\title{
PAWEŁ SZCZEPANIK
}

\section{WCZESNOŚREDNIOWIECZNE MASKI SŁOWIAN. OBRAZY ZMARŁYCH, BOGÓW, CZY REKWIZYTY RYTUALNE?*}

\author{
EARLY MEDIEVAL MASKS OF THE SLAVS: \\ IMAGES OF THE DEAD, THE GODS - OR RITUAL PROPS?
}

\begin{abstract}
Masks have played an important role in human culture since the earliest times. In the present paper Slavic masks that date back to the Early Middle Ages are analyzed. The collection of artefacts consists of extraordinary finds from Opole and their somewhat later analogies from Veliky Novgorod and its surroundings, which constitutes the whole catalogue of Slavic finds. Masks are connected with different kinds of performative activities. However, I will make an attempt to prove that in the discussed chronological and cultural context they were explicitly associated with the world of the dead. Such information can be found in several written sources related to the religious beliefs of the Slavs. The article presents possible interpretation paths that allow us to see masks as images of gods, the deceased, or to interpret them as ritual props connected with annual rites, during which hosting the dead was one of the key elements.
\end{abstract}

KEY WORDS: masks, Early Middle Ages, Slavic religious beliefs, afterlife, pre-Christian rituals

\section{WSTĘP}

Prowadzone od bardzo dawna badania nad przedchrześcijańską religią Słowian borykają się przede wszystkim z problemem ubogości źródeł

* Tekst powstał $\mathrm{w}$ trakcie realizacji projektu badawczego „Religie i ich rzeczy. Analiza porównawcza wczesnośredniowiecznych przedmiotów związanych z religijnością odkrytych na terenie Polski" finansowanego przez Narodowe Centrum Nauki (DEC-2017/24/C/HS3/00116). pisanych (por. m.in. Łowmiański 1979; Brückner 1985; Gieysztor 2006; Słupecki 1994; Sikorski 2018; Szczepanik 2018). W takiej sytuacji koniecznym staje się zwrócenie wzroku w kierunku innych źródeł, w tym materiałów archeologicznych, które

Za pomoc oraz udostępnienie fotografii zabytków z OpolaOstrówka chciałbym w tym miejscu serdecznie podziękować prof. Sławomirowi Moździochowi oraz mgr Krystianowi Chrzanowi z Ośrodka Badań nad Kulturą Późnego Antyku i Wczesnego Średniowiecza Instytutu Archeologii i Etnologii Polskiej Akademii Nauk we Wrocławiu. 
posiadają niezwykle rozbudowany potencjał poznawczy. Jak postaram się wykazać, wyjątkową w tym kontekście grupą zabytków są wczesnośredniowieczne maski, które były już przedmiotem wstępnych rozważań (Szczepanik 2012). W tekście zostaną poddane reinterpretacji znane z literatury artefakty odkryte na stanowisku w Opolu-Ostrówku i w Nowogrodzie Wielkim oraz jego najbliższych okolicach (ryc. 1). Zabytki te pochodzą zatem z ważnych ośrodków miejskich. Opole jest jednym z najstarszych miast w Polsce oraz było jedną z historycznych stolic Górnego Śląska. W latach 30. XX wieku, na wyspie Ostrówek, ulokowanej na Odrze odkryto doskonale zachowane relikty wczesnośredniowiecznego osadnictwa. Na szczególną uwagę zasługuje stan zachowania materiałów organicznych, które badane były wykopaliskowo z róż- nym natężeniem do końca lat 70. (Bukowska-Gedigowa, Gediga 1986 - tam starsza lit.). Ogromne znaczenie w skali europejskiej posiadał z kolei położony nad rzeką Wołchow, wczesnośredniowieczny Nowogród Wielki. Ten niezwykle ważny ośrodek miejski również jest badany archeologicznie od lat 30. ubiegłego wieku, po dziś dzień. Również w tym przypadku podmokły kontekst zalegania nawarstwień umożliwił zachowanie wielu niezwykle cennych artefaktów wykonanych z surowców organicznych (Brisbane 1992 - tam starsza lit.). Na obu stanowiskach odkryto pozostałości niezwykle złożonej, wielofazowej drewnianej zabudowy oraz zabytki związane $\mathrm{z}$ niemal wszystkimi dziedzinami życia (por. Bukowska-Gedigowa, Gediga 1986; Brisbane, Hather 2007). Pośród tych niezwykłych znalezisk znalazły się również interesujące nas

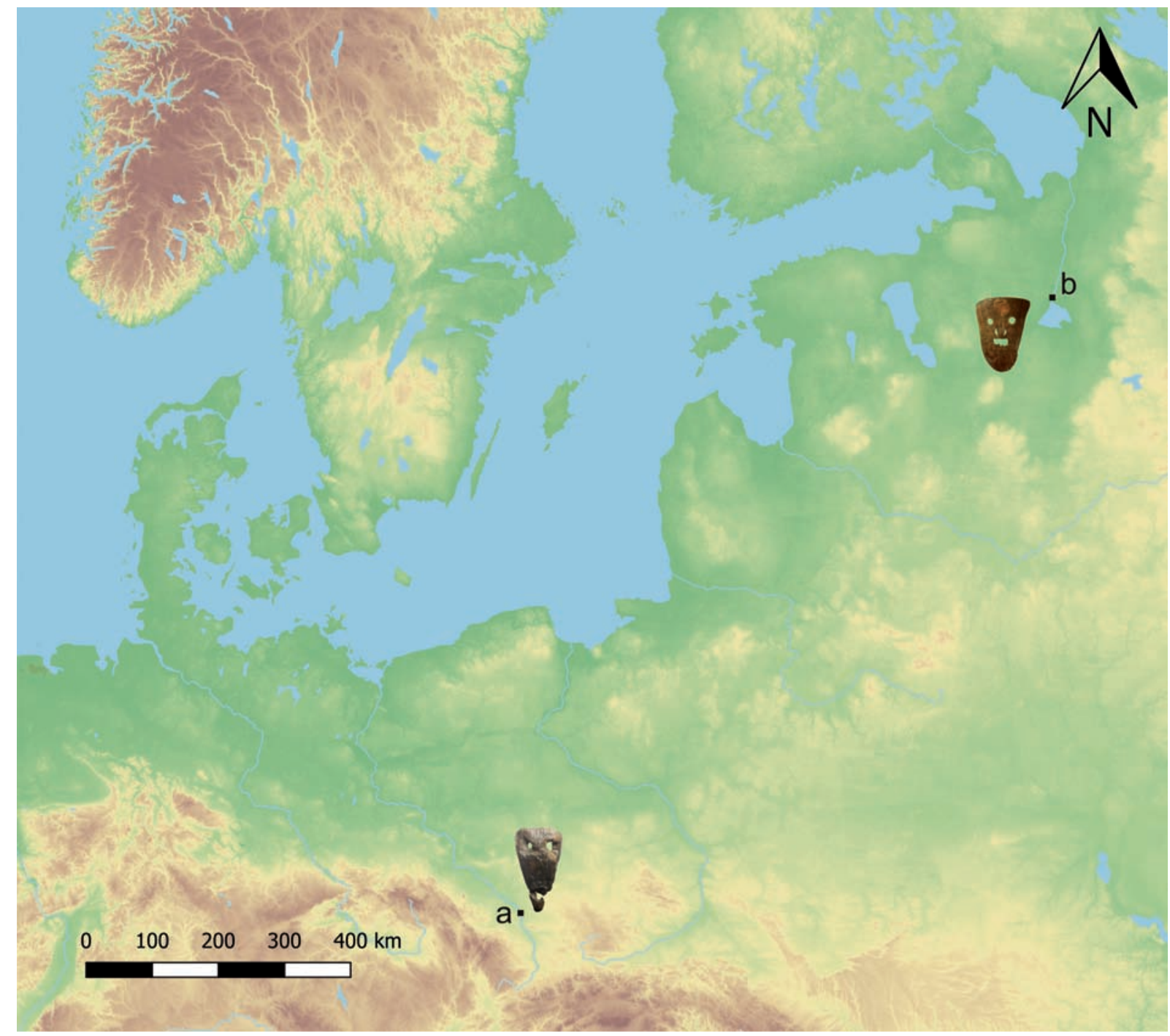

Ryc. 1. Mapa z zaznaczoną lokalizacją stanowisk: a - Opole; b - Nowogród Wielki (oprac. P. Szczepanik) Fig. 1. Map with the location of the sites marked: $a$ - Opole; b - Veliky Novogrod (by P. Szczepanik) 
zasłony twarzy wykonane $\mathrm{z}$ materiałów organicznych. Analizie zostaną poddane znaleziska dwóch drewnianych masek z Polski (Cehak-Hołubiczowa 1965; Gediga 2012) oraz zespół kilkunastu masek wykonanych ze skóry i kory brzozowej z terenów Rosji (Ovchinnikova, Kopnina 2000; Téra 2017).

\section{PRZEGLĄD MATERIAŁÓW}

W niniejszym tekście za maskę uznawać będziemy artefakt w formie twarzy ludzkiej, quasi ludzkiej lub zwierzęcej, który swoją formą umożliwiłby zakrycie twarzy. Maskami w tym rozumieniu nie będą więc płaskorzeźby przedstawiające twarze, a także inne przedmioty ozdobione twarzami bądź głowami.

Pierwsze znaleziska $\mathrm{w}$ tym typie pochodzą z wczesnośredniowiecznego Ostrówka w Opolu i to właśnie od ich opisu rozpoczniemy. Pierwsza maska została odkryta $\mathrm{w}$ warstwie datowanej na drugą połowę XI wieku (ryc. 2a). Została wykonana $\mathrm{z}$ drewna sosnowego (wysokość $34 \mathrm{~cm}$, szerokość w części czołowej $20 \mathrm{~cm}$, w części środkowej $14,2 \mathrm{~cm}$, w dolnej $7,2 \mathrm{~cm}$, grubość około $5 \mathrm{~cm}$ ). Otwory na oczy umieszczone zostały na jednym poziomie, poniżej nich znajduje się nieregularny otwór na usta. Przedmiot posiada również, schematycznie zaznaczony ryciem, nos ukazany z profilu. $\mathrm{Na}$ powierzchni maski odkryto ślady czerwonej farby (Cehak-Hołubiczowa 1965, 305-306), która być może pokrywała pierwotnie całą jej powierzchnię? Maska została odkryta w warstwie interpretowanej jako poziom śmieci, przykrytych dranicami ułożonymi podczas wznoszenia kolejnych domów. Wraz z opisanym artefaktem odkryto między innymi płozę sań, niewielki kołek drewniany, fragmenty skór, naczyń glinianych i kości zwierzęcych, a także dwa bardzo interesujące przedmioty drewniane interpretowane jako figurki koziołków (Cehak-Hołubiczowa 1965, 305).

Druga maska zachowała się niestety w niekompletnej formie (ryc. 2b). Odkryto ją w tym samym wykopie, jednak w warstwie datowanej na koniec XII w. Została wykonana $\mathrm{z}$ drewna brzozowego (wysokość $23 \mathrm{~cm}$, szerokość w części czołowej $18 \mathrm{~cm}$, w części środkowej 13,3 cm, przy zniszczonym końcu $6,3 \mathrm{~cm}$ ). Otwory oczne ułożone są na jednym poziomie, poniżej nich znajduje się jedy- nie częściowo zachowany otwór na usta (CehakHołubiczowa 1965, 305-309). W warstwie, w której zalegała maska, odkryto jeszcze materiał masowy w postaci fragmentów naczyń ceramicznych i kości zwierzęcych, nie odkryto jednak innych zabytków wydzielonych.

Odmienną formę oraz datowanie posiadają zabytki z Nowogrodu Wielkiego (ryc. 3). Zestaw ten - przywoływany zazwyczaj jako analogia do odkryć opolskich - składa się z kilkunastu pełnotwarzowych masek wykonanych ze skóry i kory brzozowej (Ovchinnikova, Kopnina 2000, 132134). Najstarsza maska $z$ tej grupy jest wykonana ze skóry i możemy datować ją na koniec XII-początek XIII wieku (ryc. 3a, 4). Jest to forma zachowana w całości (wysokość $21 \mathrm{~cm}$, szerokość w części czołowej $15 \mathrm{~cm}$ ). W skórze wycięto małe okrągłe otwory na oczy, nos, a także usta. W dolnej wardze widoczne są schematycznie ukazane zaostrzone zęby (Ovchinnikova, Kopnina 2000, 133). Powyżej linii oczu umieszczono czerwone koło, od którego promieniście odchodzą żółte linie. Całość należy interpretować jako symbol solarny. Dodatkowo widoczne są żółte linie wokół oczu oraz ust (Kolchin 1985, 31). Kolejne pięć egzemplarzy pochodzi z XIII wieku. Pierwszy z nich (ryc. 3b) ma owalny kształt (wysokość $17 \mathrm{~cm}$, szerokość $13 \mathrm{~cm}$ ) oraz zaznaczone małe trójkątne uszy/rogi, a także niewielką brodę. Maska ta jest włączona do grupy przedstawień zoomorficznych (Ovchinnikova, Kopnina 2000, 132). Następna przedstawia ludzką twarz wykonaną ze skóry (wysokość $15 \mathrm{~cm}$, szerokość 13,5 cm) (ryc. 3c, 5). Mimika zdaje się ukazywać śmiech, na co wskazują przymrużone oczy oraz kształt ust, w których mimo uśmiechu w dolnej wardze widoczne są zęby (Kolchin 1985, 30). Kolejna maska wykonana ze skóry zachowała się jedynie częściowo (wysokość $13 \mathrm{~cm}$, szerokość $12 \mathrm{~cm}$ ) (ryc. 3d). Widoczne są owalne oczy oraz prosty nos. Co istotne, na jej brzegach widoczne są dziurki, służące prawdopodobnie do przymocowania dodatkowych elementów lub do umocowania jej na głowie (Ovchinnikova, Kopnina 2000, 133). Otwory takie widoczne są na kolejnym skórzanym egzemplarzu (wysokość $22 \mathrm{~cm}$, szerokość $22 \mathrm{~cm}$ ) (ryc. 3e). Wizerunek ten ma czworoboczny kształt z zaznaczonymi owalnymi wąskimi oczami, małym trójkątnym nosem oraz wąskimi ustami (Ovchinnikova, Kopnina 2000, 133). Jeszcze jedna maska $\mathrm{z}$ tego okresu jest równie schematyczna (wysokość 20,7 cm, szerokość 20,6 cm) (ryc. 3f), choć w tym 


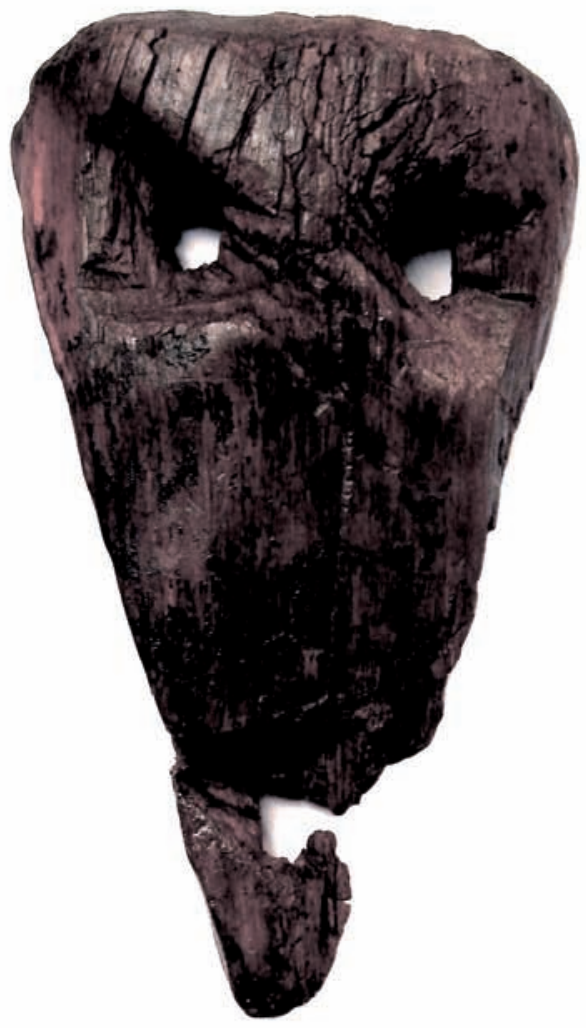

a
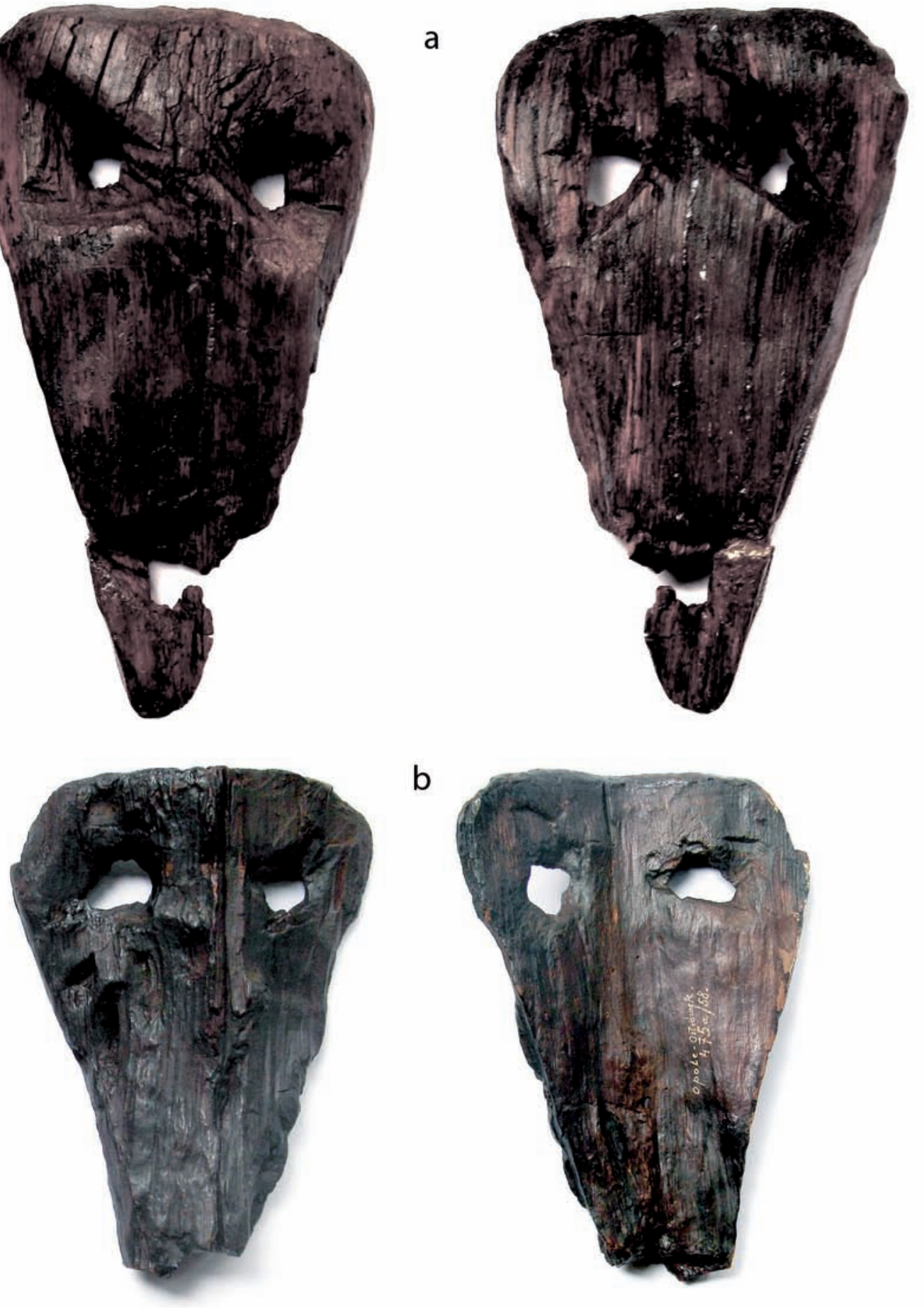

b
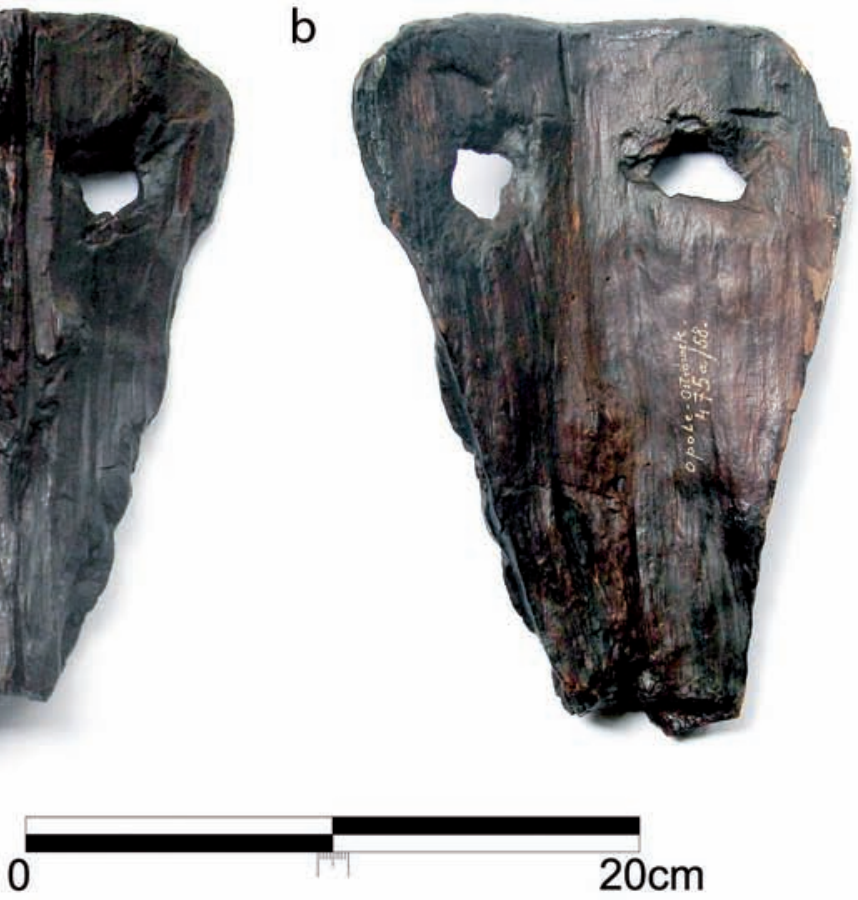

Ryc. 2. Maski z Opola-Ostrówka: a - maska z drewna sosnowego XI w.; b - maska z drewna brzozowego XII w. (fotografie zabytków ze zbiorów Ośrodka Badań nad Kulturą Późnego Antyku i Wczesnego Średniowiecza IAiE PAN - oprac. P. Szczepanik)

Fig. 2. Masks from Opole-Ostrówek: a - mask made of pine wood, eleventh century; b- mask made of birch wood, twelfth century (photographs from the collection of the Centre for Late Antique and Early Medieval Studies of the Institute of Archaeology and Ethnology of the Polish Academy of Sciences - prepared by P. Szczepanik) 


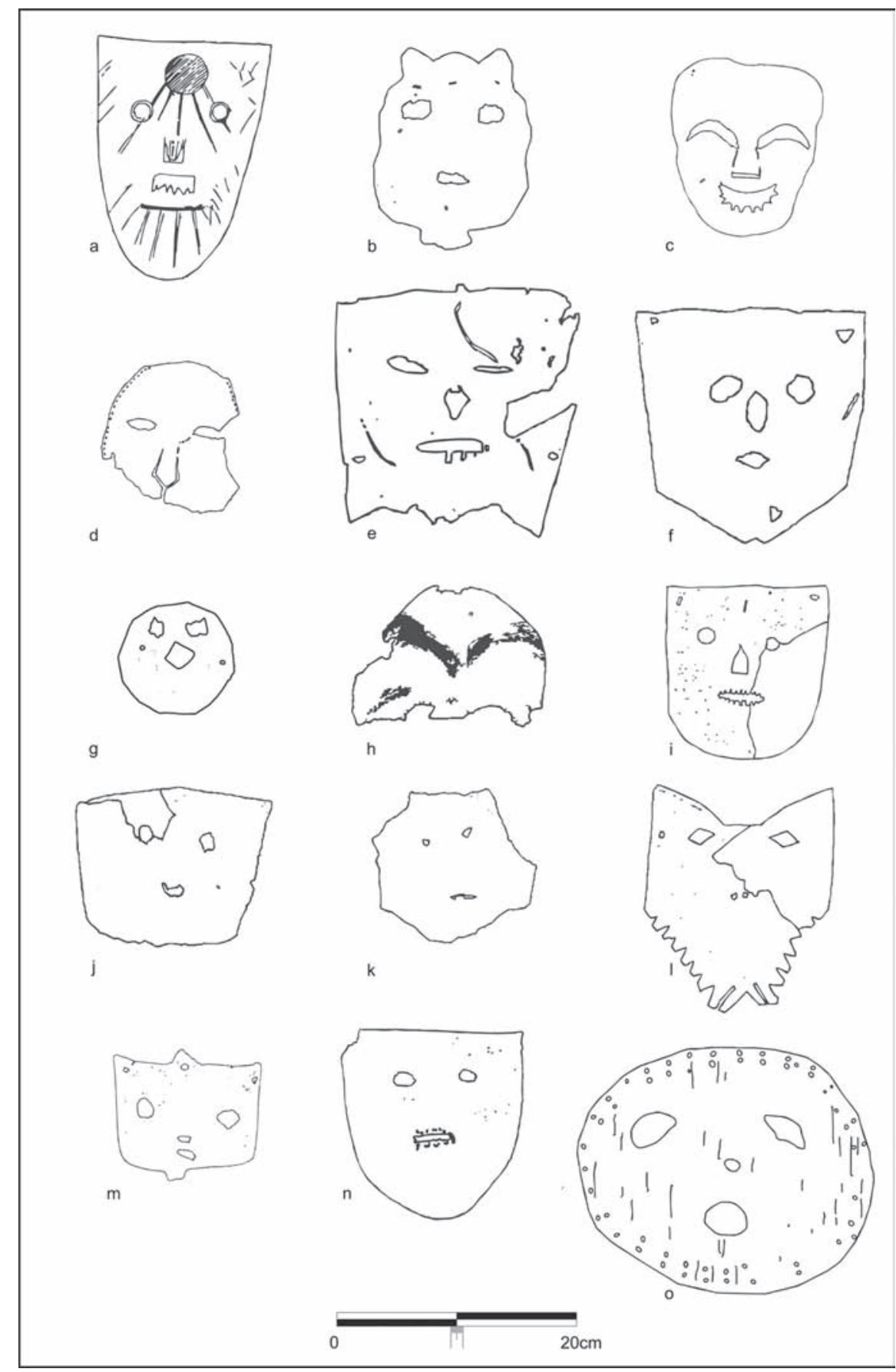

Ryc. 3. Maski z Nowogrodu Wielkiego (a-n) i Lukovec (o): a - skórzana, antropomorficzna, z wyobrażeniem Słońca XII/XIII w.; b - skórzana, zoomorficzna XIII w.; c - skórzana, antropomorficzna XIII w.; d - skórzana, antropomorficzna XIII w.; e - skórzana, antropomorficzna XIII w.; f - skórzana, antropomorficzna XIII w.; g - skórzana, antropomorficzna XIII w.; h - skórzana, antropomorficzna XIV w.; i - skórzana, antropomorficzna XIV w.; j - skórzana, antropomorficzna XIV w.; $\mathrm{k}$ - skórzana, antropomorficzna XIV w.; 1 - skórzana, zoomorficzna, chronologia ?; $\mathrm{m}$ - skórzana, antropomorficzna, chronologia ?; n - skórzana, antropomorficzna, chronologia ?; o - kora brzozowa, antropomorficzna Lukovec XI w. (za: a-f, h-o - Ovchinnikova, Kopnina 2000, fig. 1-14; g - Téra 2017, 306. Oprac. P. Szczepanik) Fig. 3. Masks from Veliky Novogrod (a-n) and Lukovec (o): a - leather, anthropomorphic, with a depiction of the Sun, twelfth/thirteenth century; $\mathrm{b}$ - leather, zoopomorphic, thirteenth century; c - leather, anthropomorphic, thirteenth century; $\mathrm{d}$ - leather, anthropomorphic, thirteenth century; $\mathrm{e}$ - leather, anthropomorphic, thirteenth century; $\mathrm{f}-$ leather, anthropomorphic, thirteenth century; $\mathrm{g}$ - leather, anthropomorphic, thirteenth century; $\mathrm{h}$ - leather, anthropomorphic, fourteenth century; $\mathrm{i}$ - leather, anthropomorphic, fourteenth century; $\mathrm{j}$ - leather, anthropomorphic, fourteenth century; $\mathrm{k}$ - leather, anthropomorphic, fourteenth century; 1 - leather, zoomorphic, chronology ?; $\mathrm{m}$ - leather, anthropomorphic, chronology ?; n - leather, anthropomorphic, chronology ?; o - birch bark, anthropomorphic, Lukovec, eleventh century (after: a-f, h-o - Ovchinnikova, Kopnina 2000, fig. 1-14; g - Téra 2017, 306. By P. Szczepanik) 
przypadku oczy są okrągłe, a otwory na nos i usta owalne (Ovchinnikova, Kopnina 2000, 134). Na XIII wiek datowane jest również najnowsze odkrycie maski, o nieco odmiennej formie. Została ona wykonana ze skóry i ma okrągły kształt (wysokość $9 \mathrm{~cm}$, szerokość 9,8 cm) (ryc. 3g). Otwory na oczy mają nieregularny kształt, zaś otwór na nos jest romboidalny. Dodatkowo po obu stronach umieszczono okrągłe otwory służące do mocowania (Téra 2017, 306).

Najmłodsza grupa artefaktów z Nowogrodu datowana jest na koniec XIII/początek XIV wieku. Pierwszym zabytkiem z tego zespołu jest górna część skórzanej maski (wysokość 12,8 cm, szerokość $16,7 \mathrm{~cm})($ ryc. 3h) z silnie zaznaczonymi brwiami (Ovchinnikova, Kopnina 2000, 133). Następna ma analogiczną formę do młodszych okazów, choć zachowana jest jedynie częściowo. Skórzana ma-

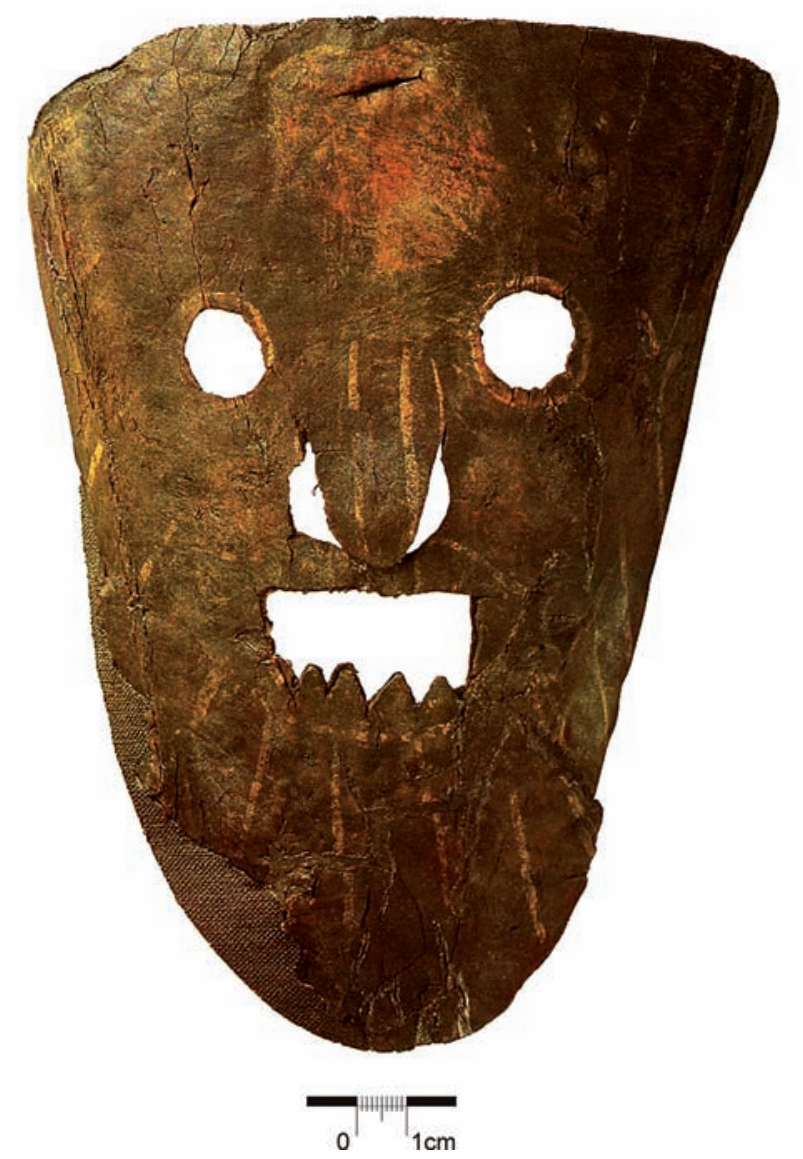

Ryc. 4. Nowogród Wielki. Skórzana maska antropomorficzna z wyobrażeniem Słońca (za: Kolchin 1985, ryc. 28. Oprac. P. Szczepanik)

Fig. 4. Veliky Novogrod. Leather anthropomorphic mask with a depiction of the Sun (after: Kolchin 1985, fig. 28. By P. Szczepanik) ska (wysokość 16 cm, szerokość 15,4 cm) (ryc. 3i) przedstawia twarz z okrągłymi otworami na oczy, trójkątnym podłużnym nosem oraz owalnymi, wąskimi ustami z widocznymi zębami (Ovchinnikova, Kopnina 2000, 133). Dwie ostatnie z najmłodszego horyzontu czasowego przedstawiają bardzo schematyczne wyobrażenia twarzy. Wykonane są ze skóry z owalnymi otworami na oczy oraz nieregularnymi otworami na usta (wymiary pierwszej z nich: wysokość $18,2 \mathrm{~cm}$, szerokość $14,7 \mathrm{~cm}$ - ryc. 3j; drugiej: wysokość $13,5 \mathrm{~cm}$, szerokość $13 \mathrm{~cm}$ - ryc. 3k) (Ovchinnikova, Kopnina 2000, 133-134). Ostatnie trzy egzemplarze $\mathrm{z}$ tego stanowiska są trudne do datowania. Fragment pierwszej ma zoomorficzną formę i przedstawia twarz ze spiczastymi uszami i brodą (wysokość $28 \mathrm{~cm}$, szerokość $16 \mathrm{~cm}$ ) (ryc. 31). Zachowany otwór na oczy ma kształt romboidalny, widoczne są również nacięcia w miejscu ust. Obok

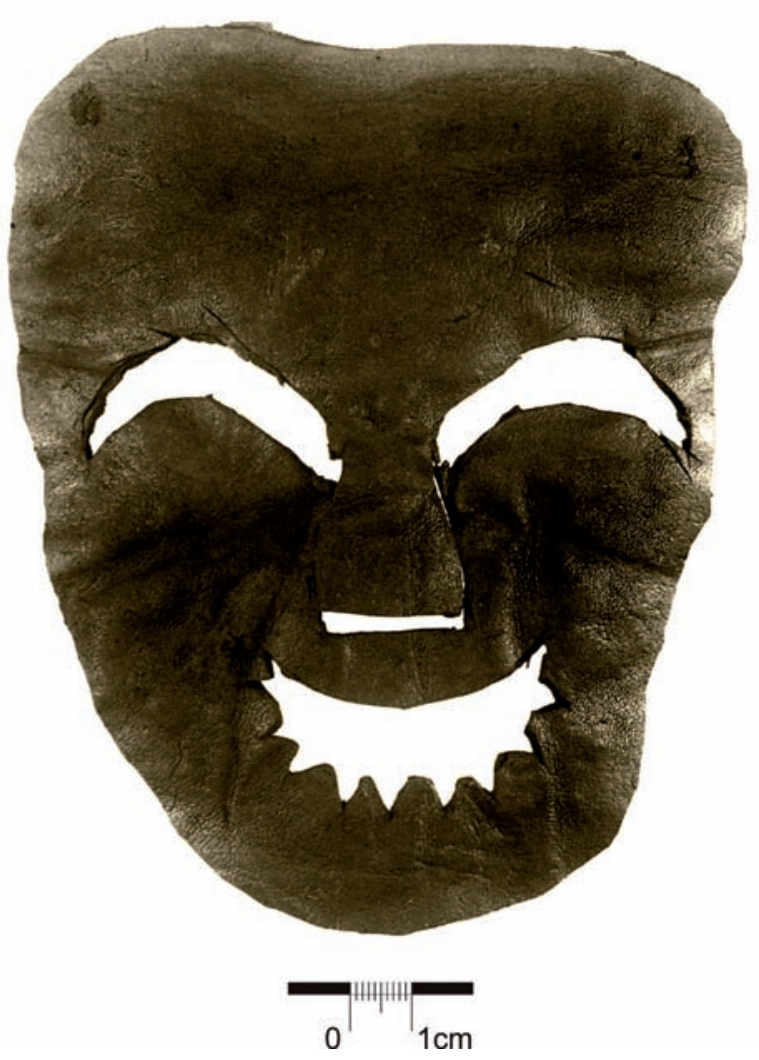

Ryc. 5. Nowogród Wielki. Skórzana maska z wyobrażeniem uśmiechu (za: Kolchin 1985, ryc. 27. Oprac. P. Szczepanik)

Fig. 5. Veliky Novogrod. Leather mask with a depiction of a smile (after: Kolchin 1985, fig. 27. By P. Szczepanik) 
oka umieszczono otwór służący zapewne do mocowania maski (Ovchinnikova, Kopnina 2000, 132). Ostatnie dwa egzemplarze mają formę antropomorficzną. Pierwsza ma kształt prostokąta (wysokość $11 \mathrm{~cm}$, szerokość 14,5 cm) (ryc. 3m) z okrągłymi otworami na oczy oraz małymi owalnymi wycięciami na nos i usta. Na dolnej krawędzi maski ukazano małą brodę, na górnej zaś trójkątny element oraz trzy otwory. Kolejne wyobrażenie antropomorficzne (wysokość 24,3 cm, szerokość $22 \mathrm{~cm}$ ) (ryc. 3n) ma prostą górną krawędź, dolna uformowana jest w ostry łuk. Poniżej prostych, okrągłych otworów na oczy umieszczono prostokątny otwór na usta, wokół którego wykonano serie mniejszych otworów (Ovchinnikova, Kopnina 2000, 134). Bezpośrednią analogią do opisanych materiałów jest znalezisko $\mathrm{z}$ grodziska Lukovec położonego w okolicach Nowogrodu. Okrągła maska została wykonana $z$ kory brzozowej (wys. 20,5 cm, szer. 24,5 cm) (ryc. 3o). Umieszczono w niej dwa nieregularne otwory na oczy, mały na nos oraz większy na usta. Na całym obwodzie maski znajdują się następne małe otwory. Przedmiot datowany jest na X - początek XI wieku (Ovchinnikova, Kopnina 2000, 130).

Jak widać, maski z terenów wczesnośredniowiecznej Słowiańszczyzny mają bardzo różną formę. Dla naszych rozważań najważniejsze są obiekty, które możemy datować na okres od X do XII wieku i wiązać z okresem przedchrześcijańskiej religijności tradycyjnej. Młodsze okazy mogą zaś być doskonałym przykładem na długie trwanie pewnych tradycji religijno-kulturowych. Najstarsze okazy zostały wykonane z kory i drewna i przedstawiają bardzo proste formy antropomorficzne. Do wykonania młodszych egzemplarzy zaczęto wykorzystywać skórę, która będąc łatwiejszą w obróbce, pozwalała na tworzenie bardziej skomplikowanych form. Od wieku XII widzimy więc próby ukazania elementów mimiki, oraz przedstawienia zoomorficzne. Pozostając przy opisie formalnym zabytków, warto zwrócić również uwagę, że tylko niektóre z nich mają widoczne do dziś ślady otworów służących do mocowania masek na twarzy. Wydaje się, że rozwiązaniem tego problemu mogło być wykorzystanie w tym celu otworów na oczy lub ścisłe obwiązywanie powierzchni masek tkaninami bądź rzemieniami.

\section{INTERPRETACJA}

Helena Cehak-Hołubiczowa wskazywała na związek masek z rytuałami około noworocznymi (polska kolęda, kolędowanie), w szczególności zaś na popularny zwyczaj zwany „chodzeniem z kozą". Taką analizę funkcji omawianych artefaktów miała uprawomocniać nie tylko ich forma, ale również odkrycie wraz z jedną z masek drewnianych figurek zoomorficznych, interpretowanych właśnie jako wyobrażenia koziołków (Cehak-Hołubiczowa 1965, 315-317). Podobną interpretację, wykorzystującą przede wszystkim ustalenia etnograficzne (Moszyński 1939, 986-1008), znajdziemy w najnowszych opracowaniach znalezisk z Opola zaproponowanych przez wieloletniego badacza wczesnośredniowiecznego Ostrówka, Bogusława Gedigę, który wpisuje maski w kontekst wierzeń przedchrześcijańskich (Gediga 2012, 125-127). Sławomir Moździoch interpretuje znaleziska jako przeżytki rytuałów pogańskich, które mogły przetrwać już po formalnej konwersji państwa Piastów (Moździoch 2013, 553), które być może związane są z tzw. reakcją pogańską z lat 30. XI wieku (Moździoch 2013a, 554). Analizy te, wykorzystujące jako materiał porównawczy przede wszystkim kulturę ludową Słowian, skupione są w głównej mierze na ukazaniu roli masek w rytuałach związanych z przesileniem zimowym i okresem noworocznym. Podczas tych obrzędów uczestnicy przebierali się w stroje i maski, a ich działania skierowane były jednocześnie w kierunku zapewnienia dobrobytu i płodności oraz w kierunku sfery śmierci i odradzającego się życia (Cehak-Hołubiczowa 1965, 316).

W podobny sposób była dotychczas interpretowana funkcja masek z terenów Rusi. Według Borysa Rybakova są one przejawem obrzędów nie tyle ściśle pogańskich, co charakterystycznych dla okresu tzw. dwuwiary (ros. dwojewierije) (Rybakov 1987, 455-459; na temat tego pojęcia por. m. in.: Chamajko 2007, 86-115; Rock 2007, 1-15; Krawiec 2017, 275-276). Bronislava Ovchinnikova dzieli zespół wschodniosłowiańskich masek na wyobrażenia zoomorficzne, antropomorficzne i mieszane. Podział ten jest ważny, ponieważ ma on odzwierciedlać się w odrębnym przeznaczeniu każdego z typów. I tak, zgodnie ze starszymi ustaleniami, wyobrażenia zoomorficzne miały być wykorzystywane podczas tzw. święta niedźwiedzi (ros. miedwieżyj prazdnik). W nowszych opraco- 
waniach znajdziemy interpretacje rozpatrujące te wyobrażenia jako wizerunki kotów lub nawet lwów (Ovchinnikova 2013, 227). Co ciekawe, podobne maski wykonane $\mathrm{z}$ wełny - mające przedstawiać rzekomo pyski niedźwiedzi - datowane na $\mathrm{X}$ wiek, zostały odkryte w Hedeby (Back Danielsson 2007, 136-137). Przez swoją formę miały być również interpretowane jako elementy związane ze świętem ku czci tych zwierząt. Według najnowszych ustaleń omawiane fragmenty są raczej elementami kapturów niż masek, bez żadnych widocznych zoomorficznych czy antropomorficznych konotacji (Bregenhøj 2012, 112-113).

Wróćmy jednak do zabytków z Nowogrodu Wielkiego. Analizy masek antropomorficznych i mieszanych są bardziej złożone. Niektórzy badacze widzieli $\mathrm{w}$ nich dowody na wczesnośredniowieczne korzenie rosyjskiego teatru (Awdiejew 1959), a maski miały być atrybutami wędrownych aktorów, kuglarzy (ros. skomoroh) znanych z kultury średniowiecza. W końcu zaś miałyby być to maski używane przez pogańskich kapłanów (rus. wołchw) (Ovchinnikova 2013, 228-229). Obecnie najczęściej przyjmuje się interpretację, według której maski - podobnie jak znaleziska z Opola - były wykorzystywane w trakcie Bożego Narodzenia oraz podczas obrzędów około noworocznych i karnawału (ros. maslenitsa). Co ciekawe, we wschodniosłowiańskiej kulturze ludowej maski miały być używane podczas noworocznych obrzędów ku czci zmarłych (ros. igra v pokoynika) (Ovchinnikova, Kopnina 2000, 128). Obrzędy te miały rezurekcyjny charakter związany z zimowym przesileniem, a wykorzystywane podczas nich maski były elementem strojów uczestników przebranych za zmarłych (Ovchinnikova 2013, 229-230).

\section{DYSKUSJA}

Spróbujmy zaproponować nowe możliwości interpretacyjne związane $\mathrm{z}$ funkcją $\mathrm{i}$ znaczeniem słowiańskich masek i wskazać ich pierwotne znaczenie, przed przejściem do sfery wierzeń ludowych i folkloru. Rozważania rozpoczniemy od definicji. Termin maska ma bowiem inne znaczenie w: teatrologii, religioznawstwie, psychologii czy antropologii kulturowej. Zacznijmy jednak od etymologii. Aleksander Brückner podaje, że pol. maska pochodzi od łac. masca lub wprost od fran. masque. Taka etymologia, charakterystyczna dla większości języków europejskich, ukazuje bezpośredni związek z maszkarami, tj. komediantami (Brückner 2000, 324). W języku łacińskim istniało jednak kilka pojęć określających maskę - co okaże się istotne przy analizie źródeł pisanych - a najbardziej interesujące to larva i persona. Pierwszy termin jest źródłosłowem pol. larwa, oznaczającego maskę, maszkarę bądź marę (Brückner 2000, 290). Kolejny określa 'widziadło senne, urojenie, marzenie' i pochodzi z kolei od psł. dial. *mara 'widziadło, przywidzenie, urojenie', to zaś prawdopodobnie od pie. *mer- 'błyszczeć, lśnić, migać', ale także 'mrzeć, umierać'. Tu z kolei widocznym jest związek z psł. *mŕtvz 'umarły, nieżywy' oraz łac. mortuus 'zmarły, martwy' (Boryś 2005, 314-315). Już na poziomie językoznawczym widać zatem potencjalny związek maski ze śmiercią i światem zmarłych. Jak postaram się wykazać, elementów poświadczających taki związek, w pogańskiej religii Słowian, jest znacznie więcej. Łaciński termin larvae 'czynić czary' (Bańkowski 2000, 5) wywodzi się z ie. *las-, a jego pierwotna forma lārua, lārva oznacza jednocześnie 'maskę', ale i 'ducha' (Pokorny 1959, 654). Maska staje się w takiej optyce metaforą larwy-poczwarki, a jej głównym zadaniem jest umożliwianie transformacji. Drugi termin to łac. persona, ukazuje on pierwotny związek maski i osoby, nadając przedmiotowi dynamicznych cech i sprawczości (agency). Etymologia zdradza pierwotne sensy nakładane na maski, które wykraczały daleko poza funkcję umożliwiającą zakrycie twarzy. Łacińska persona jest terminem wielce intrygującym, jeśli chodzi o psychologiczną rolę masek oraz o ich bezpośredni związek z zaświatami. Człowiek posiadający maski przodków to człowiek posiadający społeczno-kulturową tożsamość wynikającą z przynależności do konkretnego rodu (Mauss 2001, 190). Żyjący są zatem reprezentantami przodków, zaś atrybutami konkretnej persona są simulacra i imagines (Mauss 2001, 191). Maska jest wizerunkiem - obrazem zmarłego, obdarzonego konkretną osobowością, która przez maskę i w masce się objawia. Jest ona zatem idealną metaforą ciała, zarówno tego zmarłego, jak i żywego, jednocześnie ukrywa, ale też i unaocznia.

Nie sposób mówić o masce bez opisania jej roli w teatrze. Co znamienne, badacze teatru poszukują genezy zasłon twarzy właśnie w religijności przedchrześcijańskiej, gdzie miały być używane podczas 
ceremonii i obrzędów religijnych odprawianych na cześć przybyszów, gości i zmarłych (Hartnoll 1967, 623). Związek zmarłych z przybyszami widoczny jest między innymi w ie. ghosti-s oznaczającego 'gościa, przybysza, obcego, wroga', od którego pochodzą niem. gast i ang. ghost oznaczające wprost 'ducha' (Pokorny 1959, 453). Maska odgrywała w końcu ogromną rolę w sacer ludu - rytuałach teatralnych, mających przede wszystkim ukazać tryumf życia nad śmiercią. W obrzędach tych najczęściej występowało dwóch aktorów, jeden wyobrażał życie, drugi śmierć. Ściślej mówiąc, jeden - życie, które umiera; drugi - życie, które powstaje (Leeuw 1991, 5). Taki charakter miały również słowiańskie obrzędy około noworoczne, w tym także wspomniany już obrzęd chodzenia z kozą (Kielak 2017, 371-378 - tam starsza lit.).

Słowiańskie maski były zatem obdarzone swoistą siłą sprawczą. Ich rola polegała na zmianie rzeczywistości. Ich metamorficzny charakter dotyczył nie tylko osób, które je zakładały, ale także wszystkich uczestników danego obrzędu, którzy dzięki nim mogli przenieść się w świat mityczny. Ów świat może ukazywać się w obrzędzie teatralnym, który jest zdesakralizowaną formą aktywności religijnej. Pierwotne, rytualne doświadczenie metamorfozy jest więc prototypem zachowań aktorskich. Owa metamorfoza miała charakter zarówno wewnętrzny - psychiczny, jak i zewnętrzny - symbolizowany przez maskę. Wszystkie te elementy nieodłącznie związane są w tradycji antycznej z kultem Dionizosa, którego maska jest emblematem całego teatru i jednocześnie obrazem samego bóstwa (Kolankiewicz 1999, 46). Gerardus van der Leeuw twierdzi w tym kontekście, że „bóg jest maską, maska bogiem" (Leeuw 1991, 6). Chtoniczne kompetencje Dionizosa ukazują po raz kolejny pierwotny związek teatru i kultu zmarłych - pierwsi aktorzy ,wyróżniali się ze zbiorowości grając role Zmarłych" (Kolankiewicz 1999, 210).

Maska ma umożliwić człowiekowi kontakt z pierwotną sferą dzikiej, chaotycznej natury (pierwiastek chtoniczny $=$ dionizyjski), ponieważ ,tak jak natura czy nawet stan dzikości towarzyszyły masce, tak też maska od zawsze towarzyszyła człowiekowi" (Kerényi 2005, 648). W antropologicznym rozumieniu główną funkcją maski jest zatem stwarzanie płaszczyzny dla komunikacji ze zmarłymi, bogami, ale także z samym sobą (Boholm 2005, 658). Co za tym idzie, to nie sama forma i kształt, ale rekonstruowany kontekst rytualnego wykorzy- stania masek stanowi o jej charakterze i związkach z obrzędami ku czci zmarłych i zaświatami. Nasza analiza staje zatem przed pytaniem: czy możliwe jest ukazanie właśnie takiej roli masek w kontekście religii wczesnośredniowiecznych Słowian? Próbę odpowiedzi na to pytanie zacznijmy od przeglądu źródeł pisanych.

Pierwszy interesujący nas passus znajdziemy w „Kronice Czechów” Kosmasa (III, 1). Dziejopis przytacza wydany przez księcia Brzetysława dekret z 1092 roku, w którym monarcha zabrania urządzania pogańskich rytuałów pogrzebowych, podczas których uczestnicy, tańcząc z założonymi maskami, przywołują dusze zmarłych ${ }^{1}$. Z tekstu tego wyłania się wprost związek interesujących nas artefaktów ze sferą funeralną, podczas których przywoływane są dusze przodków. W przytoczonym fragmencie maski są jedynymi przedmiotami, które obok ludzi - i zmarłych - są uczestnikami obrzędów przybierających formę żywiołowego tańca. Niestety, z treści nie dowiadujemy się niczego na temat wyglądu tych przedmiotów. Wiemy, że były one przystosowane do założenia na twarz zapewne w dość solidny sposób, umożliwiający dynamiczne tańce. Nie wiemy jednak, jak przedstawiała się sama relacja między zamaskowanymi tancerzami a zmarłymi. Czy maski były środkiem komunikacji z nimi, czy też tak przebrani uczestnicy obrzędu mieli ich uobecniać?

Kolejny fragment nie wspomina wprost o masce, mówi on o „zasłonie" zakrywającej twarz, a właściwie twarze posągu. W relacji Ebona (III, 1), jednego $\mathrm{z}$ autorów żywotów świętego Ottona, znajdziemy informację o świątyni Trzygława mieszczącej się w Szczecinie. Sam posąg bóstwa miał mieć twarze zakryte złotą zasłoną, która miała czynić go ślepym na ludzkie grzechy². Niestety, kronikarz nie

1 „Item et supersticiosas instituciones, quasi Villani, adhuc semipagani, in pentecosten tertia sive quarta feria observabant, offerentes libamina super fontes mactabant victimas et demonibus immolabant, item sepultures, que fiebant in silvis et in campis, atque scenas, quas ex gentili ritu faciebant in biviis et in triviis quasi ob animarum pausationem, item et iocos profanes, qous super mortus suos inanes cientes manes ac induti faciem larvis bachando exercebant, has abhominationes et alias sacrilegas adinventiones dux bonus (...)" (Cosmas III, 1, 161).

2 „Stetin vero amplissima civitas et maior Iulin tres montes ambitu suo conclusus habebat, quorum medius, qui et alcior, summo paganorum deo Trigelawo dicatus, tricapitum habebat simulacrum, quo aurea cidari oculos et 
podaje informacji na temat formy tej zasłony. Warto przybliżyć nieco postać samego Trzygława i jego mitycznych kompetencji. Bóstwo to wywodzi swój charakter wprost ze sfery chtonicznej, podziemnej i być może wraz z rozwojem miejscowego ośrodka kultowego nabrało cech uniwersalnych (Rosik 2010, 264-265). Poza Szczecinem, miejsce jego kultu miało znajdować się także w Brandenburgu (por. Słupecki 1993, 38). Według ustaleń badaczy religii Słowian, Trzygław jest jednym z odpowiedników Welesa, opiekuna świata zmarłych, ale także bogactwa, urodzaju, magii i bydła, którego atrybutami było złoto i czarny wierzchowiec (Gieysztor 2006, 147-153; Dynda 2014, 71-74; Szczepanik 2018, 46). Na bezpośredni związek Welesa z zaświatami wskazuje również ofiara ku czci zmarłego, znana z latopisów ruskich tryzna (Gieysztor 2006, 259). W tradycji ludowej zwyczaj ten zachował się na większości terenów słowiańskich pod postacią ,zastawy zadusznej” (Moszyński 1934, 253). Tryzna związana była z rytualnym piciem alkoholu, którego celem było zapewne wywołanie stanu oszołomienia, „będącego substytutem mistycznego żaru” (Kowalik 2004, 379). Podobne elementy znajdziemy w rekonstrukcjach Borysa Uspieńskiego zakładających, że w tradycji wschodniosłowiańskiej św. Mikołaj przejął kompetencję przedchrześcijańskiego Welesa. Stan upojenia alkoholowego miał być mocno związany z obchodami dnia tego świętego, podczas którego składano ofiarę z trzyletniego byka - tzw. mikolszczyznę (Uspieński 1985, 76-77). W ofiarach unaocznia się związek Trzygława, oraz liczby trzy, ze światem pozagrobowym.

Tak rekonstruowana postać Trzygława to bóstwo wszechwiedzące (Pettazzoni 1968, 211-236). Ebo próbuje zrozumieć rolę złotej maski, używając chrześcijańskiego aparatu pojęciowego i kategorii grzechu. Należy założyć jednak, że kategoria taka była nieznana w przedchrześcijańskiej religii Słowian (Szczepanik 2018, 143-144). Właściwa funkcja maski musiała zatem być inna. Zasłona ta miała raczej na celu ukrycie boskich oblicz, których oglądanie w bezpośredniej formie podlegało zapewne swoistemu tabu. Ślady takiego zachowania mogą być widoczne w dostępie do posągu Świętowita

labia contegebat, asserentibus idolorum sacerdotibus ideo summum deum tria habere capita, quoniam tria procura ret regna, id est celi, terre et inferni, et faciem cidari operire pro eo quo peccata hominum, quasi non videns et tacens, dissimularet (...)" (Ebo III, 1, 93). w świątyni w Arkonie. Według Saxo Grammaticusa kapłan, który wchodził do pomieszczenia, gdzie stał posąg, wstrzymywał oddech, aby nie skalać nim bóstwa ${ }^{3}$. Maska Trzygława mogła więc spełniać podobną rolę. W przedmiocie tym skupia się niejako istota fenomenu - jednocześnie zakrywając jedną twarz, ukazuje drugą. Być może w końcu zasłona znajdująca się na posągu Trzygława stanowiła swoisty atrybut bóstwa, analogicznie do maski Dionizosa? Opis ten ukazuje nam kolejną możliwość ich funkcjonowania $\mathrm{w}$ religii Słowian, odmienną od tej zapisanej w kronice Kosmasa. Obie skierowane są jednak w stronę sfery funeralnej. Maski były bowiem przede wszystkim wykorzystywane podczas obrzędów ku czci przodków - pol. Dziady, podczas których zmarli przybywali w gościnę, aby się ogrzać i posilić. Rytuały takie miały odbywać się kilka razy do roku i związane były bezpośrednio z cyklem słonecznym (Szczepanik 2018, 118-120). Związek z nim wydaje się poświadczać w sposób jednoznaczny jedna z masek nowogrodzkich ozdobiona wyobrażeniem solarnym.

Pozostając przy formie znanych nam artefaktów, warto zwrócić uwagę na kształt opolskich masek. Przedmioty te zostały uformowane na kształt wydłużonych trójkątów, co może być z jednej strony związane z prostotą i schematyzmem przedstawienia, z drugiej może mieć uzasadnienie na płaszczyźnie symbolicznej. Numerologia w kontekście kultur tradycyjnych to z pewnością temat na osobne opracowanie (por. Widomski 1996). Warto jednak zasygnalizować, że liczba trzy miała pełnić rolę swego rodzaju ,absolutnej doskonałości”, służącej za ,idealny obraz dowolnego procesu dynamicznego dopuszczającego powstanie, rozwój i upadek, lub - w nieco innym planie - tezę, antytezę i syntezę" (Toporow 1974, 179). Trójdzielność, obok dualizmu, jest również jedną z podstawowych cech słowiańskiej kosmologii: rzeczywistość podzielona jest na świat niebios, świat ziemski oraz świat podziemi (por. szerzej na ten temat Szczepanik 2018, 43-47). Związek ten widoczny jest we wspomnia-

3 „Huius sacerdos, praeter communem patriae ritum barbae comaeque prolixitate spectandus, pridie quam rem divinam facere debuisset, sacellum, quod ei soli intrandi fas erat, adhibito scoparum usu diligentissime purgare solebat, observato, ne intra aedem halitum funderet; quo quoties capessendo vel emitiendo opus habebat, toties ad ianuam procurrebat, ne videlicet dei praesentia mortalis spiritus contagio pollueretur (...)" (Saxo XIV, 39, 565). 

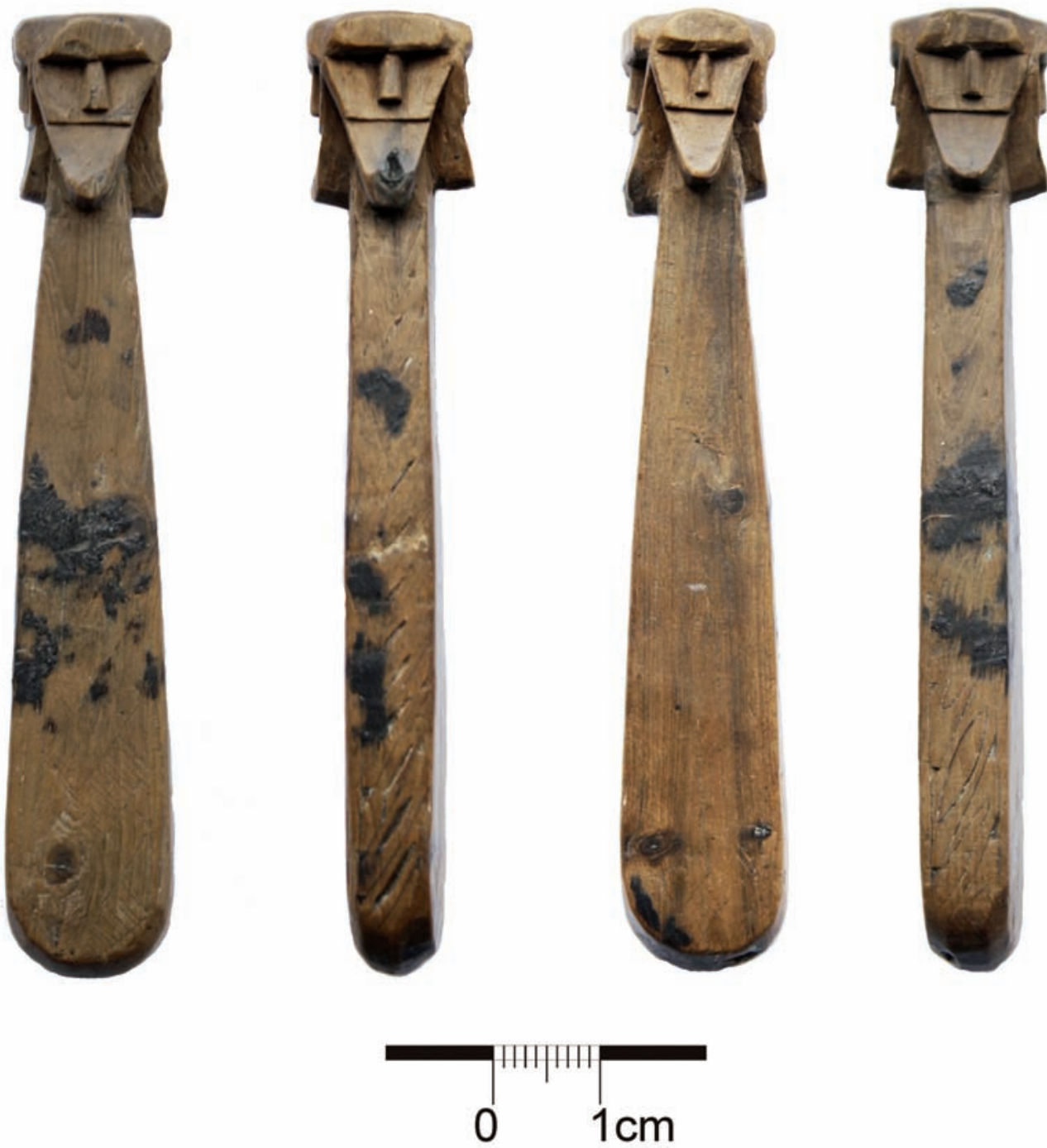

Ryc. 6. Wolin. Drewniana figurka czterotwarzowa, tzw. Światowit (fot. i oprac. P. Szczepanik)

Fig. 6. Wolin. Wooden four-faced figurine, the so-called Światowit (photograph and processing by P. Szczepanik)

nych już ofiarach dla zmarłych w typie tryzny (por. wyżej). Wracając jednak do trójkątnego kształtu śląskich masek, warto zwrócić się ku innym zabytkom związanym ze sferą pogańskiego sacrum. W tym kontekście unaocznia się podobieństwo do twarzy zdobiących drewnianą figurkę tzw. Światowita z Wolina (ryc. 6). Oczywiście jest to inna kategoria przedmiotu (por. Szczepanik 2018a, 45-46), jednak sposób ukształtowania obrysów poszczególnych twarzy, z szerokim płaskim czołem oraz wydłużoną, półokrągle zakończoną brodą, wydają się być dalece analogiczne.

Wróćmy jednak do informacji płynących z kolejnych, mniej znanych źródeł pisanych (Szczepanik 2012, 111-114). Teksty te są nieco młodsze od omówionych wyżej kronik, a ich wymowa jest ściśle związana $\mathrm{z}$ wykorzenianiem przez chrześcijańskie duchowieństwo pogańskich obyczajów już po formalnej chrystianizacji. Pierwszy $z$ nich to dekret papieża Innocentego III z 8 stycznia 1207 roku. W liście tym znajdziemy zapis 'monstra larvarum' (Kodeks I, dok. 55) oznaczający 'maski duchów, potworów; maszkary', odnoszący się do wyglądu uczestników obrzędów, które miały być odprawiane w katedrach i kościołach archidiecezji gnieźnieńskiej, właśnie ku czci zmarłych. W rytuałach tych aktywny udział, połączony z recytacją konkretnych ról, brało całe duchowieństwo, wraz $\mathrm{z}$ wiernymi. Podczas tych ludi theatrales uczestnicy mieli na twarzach maski (Burchardt 1986, 35). 
Po raz kolejny widzimy więc związek pomiędzy maskami i śmiercią. Trzeba podkreślić, że obrzędy te miały odbywać się jeszcze w początkach XIII wieku w jednej z najważniejszych chrześcijańskich świątyń ówczesnej Polski. W okresie przed przyjęciem chrześcijaństwa Góra Lecha miała być miejscem kultu Nyji, bogini określonej przez Jana Długosza mianem słowiańskiego Plutona ${ }^{4}$. O ile badacze $\mathrm{z}$ dużą ostrożnością podchodzą do tzw. Panteonu Długoszowego, to Nyja wydaje się nie budzić wątpliwości co do swojego przedchrześcijańskiego charakteru (Brückner 1985, 41-42; Witczak 1994; Strzelczyk 1998, 138; Gieysztor 2006, 197). Co ciekawe, podczas prac archeologicznych prowadzonych pod kościołem św. Jerzego - w najwyższym punkcie Góry Lecha, odkryto konstrukcję kamienną którą odkrywcy skłonni są interpretować jako swoisty kopiec ofiarny (Sawicki 2001, 180) lub ostatnio jako rodzaj grobu mniej lub bardziej mitycznego protoplasty (Sawicki 2017, 693). Zostawiając kwestię interpretacji tego wyjątkowego obiektu archeologicznego do dalszych rozważań, należy podkreślić mityczne znaczenie gnieźnieńskiego wzgórza $\mathrm{w}$ procesie budowania wspólnoty państwowej bezpośrednio związanej z pamięcią o przodkach (Szczepanik 2018, 92-95 - tam dalsza lit.).

Przejdźmy do kolejnych źródeł pisanych i występujących w nich masek. W statucie arcybiskupa gnieźnieńskiego Janisława z 19 lutego 1326 roku ponownie pojawia się zapis monstris larvarum (Kodeks II: dok. 1061). Nakazuje on, żeby księża oraz ludzie świeccy nie przebywali na cmentarzach i w kościołach ubrani w maszkary, podczas odbywających się nabożeństw (Gloger 1903, 427). Maski wykorzystywane w tych obrzędach interpretowane są tym razem wprost, jako postacie duchów nieczystych (Kowalska-Lewicka 1986, 23). W tym zakazie kościelnym maski wykorzystywane są zarówno przez duchowieństwo, jak i ludność świecką. Pojawia się również nowa przestrzeń obrzędowa - obok kościołów są to cmentarze. Schemat działań rytualnych pozostaje jednak ten sam.

4 „Pluthonem cognominabant Nya, quem inferorum deum et animarum, dum corpora linquunt, servatorem et custodem opinabantur; postulabant se ab eo post mortem in meliores inferni sedes deduci et illi delubrum primarium in Gneznensi civitate, ad quod ex omnibus locis fiebat congressus, fabricarunt”' (Długosz I, 106).
Przedstawione teksty są reakcją hierarchów Kościoła na obrzędy odprawiane ku czci zmarłych, podczas których noszono maski. Na związek z rytuałami pogrzebowymi może wskazywać również drobny szczegół formalny analizowanych zabytków archeologicznych, jakim jest mimika widoczna na niektórych skórzanych egzemplarzach. Jak bowiem wiemy z relacji Ibrāhīma ibn Ja'qūba w przekazie al-Bakrīego, słowiańskim pogrzebom ciałopalnym miała towarzyszyć radość żałobników: „Oni [tj. Słowianie - P.S.] głośno objawiają radość i cieszą się przy spaleniu zmarłego i twierdzą, że ich radość i głośne oznaki wesela (pochodzą) stąd, że pan jego (tj. zmarłego) zmiłował się nad nim" (Kowalski 1946, 53). Wspomniana radość może być interpretowana jako wyraz braku lęku przed śmiercią i pozytywna waloryzacja zaświatów (Szczepanik 2018, 113-116 - tam starsza lit.). Widoczny na niektórych maskach uśmiech może więc być echem potrzeby ukrycia smutku lub innych elementów niepożądanych $w$ trakcie rytuału pogrzebowego. W takiej optyce forma konkretnych wytworów mogłaby być związana bezpośrednio z konkretnymi wierzeniami eschatologicznymi.

Zestawienie powyższych źródeł nie jest przypadkowe. Ukazuje ono przynajmniej dwie możliwości funkcjonowania masek w religii pogańskich Słowian. Mogły odgrywać rolę atrybutów rytualnoobrzędowych lub być swoistymi manifestacjami obecności zmarłych i/lub bóstw związanych ze sferą chtoniczną. Do pierwszej grupy należą przedmioty, które są niezbędne dla prawidłowego przebiegu rytuału. Maski posiadają w tym kontekście niezwykle wysokie dynamis - nadnaturalną moc sprawczą (Belting 2010, 12). Można powiedzieć, że obrzęd ku czci zmarłych jest aktem religijnym, a nie zwykłą czynnością społeczną między innymi właśnie dzięki tym przedmiotom. W takiej perspektywie służyły one ,ucieleśnianiu duchów i zmarłych, którzy swoje ciała utracili, użyczając im niejako twarzy oficjalnych" (Belting 2015, 44). Właśnie taką rolę mogły pełnić maski w rytuałach pogrzebowych przedstawionych przez Kosmasa, a także w obrzędach ku czci zmarłych, których zakazywał papież Innocenty III czy arcybiskup Janisław. Maski stają się niezbędne do komunikacji ze światem zmarłych, będąc aktywnymi ,graczami” tych obrzędów (por. Latour 2010, 525-560). Spełniają one podstawowe funkcje rytualne: umożliwiają przywołanie zmarłych, zapewniają kontakt $\mathrm{z}$ nimi oraz zapewniają swoistą ochronę przed negatywnymi skutkami ta- 
kiego kontaktu. Trudno stwierdzić, czy miały one chronić wkładających je uczestników obrzędów przed rozpoznaniem i zapewniać anonimowość we wspólnocie żywych i umarłych, czy też miały zabezpieczać ich przed innymi zabiegami magicznymi? Z pewnością sprawiały, że działania ludzkie nabierały nowego wymiaru. Człowiek zakładający maskę przestawał być sobą, a stawał się postacią przez nią reprezentowaną (Leeuw 1991, 6).

Maski mogły być również obrazami - przedstawieniami zmarłych. Według Leszka Kolankiewicza, badacza pogańskich źródeł teatru, pierwotnie wszystkie rytualne maski reprezentują dusze zmarłych, a „tańce w maskach, są zawsze tańcami duchów" (Kolankiewicz 1999, 46). W takim ujęciu zamaskowani uczestnicy obrzędów nie mają już tylko zapewnić komunikacji ze zmarłymi, oni się nimi stają. Maska, jako atrybut rytualno-obrzędowy, jest narzędziem pozwalającym na prawidłowy przebieg całości zabiegów religijnych. Zapewnia uczestnikom rytuału komunikację ze zmarłymi, pozwalając na ich uobecnienie oraz zjednoczenie się z nimi (Szczepanik 2012, 113-114). Niestety nie wiemy, czy maski poza okresem uroczystości posiadały jakąś szczególną rolę lub były obiektem jakiejkolwiek czci. Wydaje się, że mogły one tracić swoje symboliczne znaczenie wraz z końcem obrzędu. Taki przebieg wydarzeń wydają się sugerować konteksty odkrycia poszczególnych zabytków archeologicznych w nawarstwieniach śmietniskowych. Również wykonanie $\mathrm{z}$ surowców organicznych poddających się łatwej obróbce (Aldhouse-Green 2005, 96), ale też manipulacjom i zniszczeniom, wydaje się sugerować, że przedmioty te były tworzone w konkretnym rytualnym celu, po spełnieniu którego traciły swój wysoki status znaczeniowy, a następnie były niszczone i wyrzucane.

Maski mogły odgrywać też ważną rolę w zdecydowanie odmiennych sferach słowiańskiej religijności, będąc obrazem bóstwa dostępnym dla oczu wystawców. W takiej perspektywie ma ona „chronić bóstwo, a jednocześnie ukrywać - wspominać go, ale nie wystawiać na widok" (Leeuw 1997, 391). Być może to właśnie tak należy interpretować funkcję złotej zasłony chroniącej oblicza Trzygława? Zasłona będąca swoistym fetyszem religijnym będzie w tym ujęciu przedmiotem, który determinuje zachowania rytualno-obrzędowe (Szczepanik 2012, 115-116). Aktywność ta, to zachowania „dla niego i przez niego”, nie tylko ,przy jego użyciu”, jak ma to miejsce w przypadku atrybutów - rekwizytów. To właśnie dzięki temu fetysz może być postrzegany jako obraz boga (Leeuw 1997, 33). Tak rozumiana maska Trzygława staje się numinotycznym uosobieniem treści sakralnych zmaterializowanych w konkretnym przedmiocie (Otto 1999, 10). Ten złoty artefakt uobecniał bóstwo, zapewniając komunikację pomiędzy sferą ziemską a boską. Już wcześniej odrzuciliśmy interpretację w duchu interpretatio christiana, zakładającą funkcjonowanie w religii pogańskich Słowian kategorii grzechu. Teraz widzimy, że zasłona mogła raczej pozwalać na komunikację, a nie ją ograniczać (Belting 2015, 12-14). To właśnie maska stawała się elementem skupiającym - zapewne również $\mathrm{z}$ racji materiału, z którego była wykonana - całą sakralną moc. Być może należała ona więc do kategorii ,przedmiotów świętych", które Maurice Godelier (2010, 149) nazywa „przedmiotami zastępującymi ludzi i bogów".

Zaprezentowana analiza unaocznia możliwość spojrzenia na maski jak na przedmioty o niezwykle istotnej roli w przedchrześcijańskiej religii Słowian. Przyjęta ścieżka interpretacyjna ukazuje jedną z możliwości analizy tej niezwykle interesującej grupy artefaktów, ukazując ich pierwotny związek ze światem zmarłych. Konstatacja ta wpisuje wczesnośredniowieczne materiały słowiańskie w rozważania $\mathrm{z}$ zakresu antropologii obrazu prowadzone przez Hansa Beltinga (2015, 46), według którego „W dziejach maski znajduje swoje odbicie również rodowód kultu przodków i kultu bogów". Nawet tak pozornie skromna liczba materiałów źródłowych, jakimi dysponujemy, pozwala rozpatrywać te wyjątkowe artefakty w co najmniej dwojakim świetle. Mogą być one atrybutami rytualno-obrzędowymi. Ich przykładem są maski wykonane $\mathrm{z}$ materiałów organicznych, odkrywane podczas badań archeologicznych, a które możemy wiązać z rytuałami ku czci zmarłych. $Z$ drugiej strony mogą być one obrazami zmarłych lub wręcz bóstw opiekujących się nimi, na co może wskazywać wymowa niektórych źródeł pisanych. Wraz z postępującą chrystianizacją maski, podobnie jak inne elementy pogańskiej przeszłości, przeszły drogę od przedmiotów związanych ze sferą działań religijnych do sfery folkloru i znanych do dnia dzisiejszego obrzędów kolędowania, w których wciąż widoczne są echa rytów eschatologicznych. 


\section{EARLY MEDIEVAL MASKS OF THE SLAVS: IMAGES OF THE DEAD, THE GODS - OR RITUAL PROPS?*}

\section{INTRODUCTION}

Studies on the pre-Christian religion of the Slavs, carried out for long years, are confounded by the deficiency of written sources (see: Łowmiański 1979; Brückner 1985; Gieysztor 2006; Słupecki 1994; Sikorski 2018; Szczepanik 2018). Such the case, it is necessary to look at other sources, including archaeological materials, as they offer extensive research potential. Here I will try to prove that early medieval masks, which have already been a subject of preliminary studies (Szczepanik 2012), comprise a unique group of finds. Thus, in this paper artifacts discovered at the site of Opole-Ostrówek and in Veliky Novgorod and its surroundings (fig. 1), already known from the literature, will be re-interpreted. Those artifacts come from important urban centers. Opole is one of the oldest towns in Poland and was one of the historic capitals of Upper Śląsk (Silesia). In the 1930s, on the island of Ostrówek, located in the Odra river, perfectly preserved relics of an early medieval settlement were discovered. The state of preservation of the organic material, excavated with varying intensity until the late 1970 s, deserve special attention (Bukowska-Gedigowa, Gediga 1986 - with older literature). Early medieval Veliky Novgorod, located on Russia's Volkhov river, was in turn a center of great significance on a European scale, and has been excavated from the 1930s until today. In this case, as well, the wetland archaeo-

* The text was written as part of the research project "Religions and their items. A comparative analysis of early medieval objects connected with religiosity discovered in the area of Poland" Financed by The National Science Centre (DEC-2017/24/C/HS3/00116). For his help and providing access to photographs of the artefacts from OpoleOstrówek I would like to thank prof. Sławomir Moździoch and mgr Krystian Chrzan from the Centre for Late Antique and Early Medieval Studies of the Institute of Archaeology and Ethnology of the Polish Academy of Sciences in Wrocław. logical context in which the layers were formed enabled the preservation of truly valuable artifacts made of organic materials (Brisbane 1992 - with older literature). At both sites the complex remains of wooden buildings from different phases and artifacts connected with almost every area of life have been discovered (see also: Bukowska-Gedigowa, Gediga 1986; Brisbane, Hather 2007). Among these incredible finds were also face covers made of organic materials. The present analysis will be carried out on the basis of two wooden masks from Poland (Cehak-Hołubiczowa 1965; Gediga 2012), and a collection of over ten masks made of leather and birch bark from Russia (Ovchinnikova, Kopnina 2000; Téra 2017).

\section{THE OVERVIEW OF THE MATERIAL}

In this paper I shall regard as a mask artifacts that are in the form of a human, quasi human, or animal face, and which may have been used to cover the face. Thus, relief depictions of faces and other objects decorated with faces or heads will not be considered as masks.

The first relevant finds come from early medieval Ostrówek in Opole, and so we will start with their description. The first mask was discovered in a layer dated to the second half of the eleventh century (fig. 2a). It was made of pine wood (height $34 \mathrm{~cm}$, width of the upper part $20 \mathrm{~cm}$, central part $14.2 \mathrm{~cm}$ and bottom part $7.2 \mathrm{~cm}$, thickness ca. $5 \mathrm{~cm}$ ). Holes for the eyes were placed on the same level and beneath them there was an irregular hole for the mouth. The nose, seen in profile, is also schematically carved into the object. Traces of red paint were discovered on the surface of the mask (Cehak-Hołubiczowa 1965, 305-306), something which could suggest it originally covered the whole surface. The mask was discovered in a layer interpreted as a level of litter, and was covered with planks that were placed during the construction of new houses. Together with this artifact other items were also found, including a runner from a sled, 
a small wooden pin, fragments of leather, ceramic vessels, and animal bones - as well as two very interesting wooden objects interpreted as goat figurines (Cehak-Hołubiczowa 1965, 305).

Unfortunately, the second mask has survived incompletely (fig. 2b). It was discovered in the same trench, yet in a layer dated to the end of the twelfth century. It was made of birch wood (height $23 \mathrm{~cm}$, width of the upper part $18 \mathrm{~cm}$, central part $13.3 \mathrm{~cm}$, damaged end $6.3 \mathrm{~cm}$ ). Eye holes are placed at the same level, below them there is an only partially preserved mouth hole (Cehak-Hołubiczowa 1965, 305-309). The layer in which the mask was deposited also yielded mass material in the form of fragments of ceramic vessels and animal bones, but no unique artefacts.

The artifacts from Veliky Novgorod have a different form and chronology (fig. 3). The collection - usually referred to as analogous to the Polish finds - consists of over ten full-face masks made of leather and birch bark (Ovchinnikova, Kopnina 2000, 132-134). The oldest mask from the collection is made of leather and can be dated to ca. 1200 (fig. 3a, 4). It is fully preserved (height $21 \mathrm{~cm}$, width of the forehead part $15 \mathrm{~cm}$ ). Small round holes for the eyes, nose and mouth were cut in the leather. Schematically depicted sharp teeth are visible on the lower lip (Ovchinnikova, Kopnina 2000, 133). Above the eye level a red circle with yellow rays was painted. The whole should be interpreted as a solar symbol. Additionally, yellow lines around the eyes and mouth are visible (Kolchin 1985, 31). Another five masks come from the thirteenth century. The first one is oval (height $17 \mathrm{~cm}$, width $13 \mathrm{~cm}$ ) (fig. 3b), and has small triangular ears/horns and a small chin marked. This mask was included in the group of zoomorphic depictions (Ovchinnikova, Kopnina 2000, 132). The next one represents a human face made of leather (height $15 \mathrm{~cm}$, width $13.5 \mathrm{~cm}$ ) (fig. 3c, 5). The facial expression suggests a smile, which is indicated by squinted eyes and the shape of the mouth, in which, despite the smile, teeth are visible in the lower lip (Kolchin 1985, 30). Another mask made of leather was preserved only partially (height $13 \mathrm{~cm}$, width $12 \mathrm{~cm}$ ) (fig. 3d). Oval eyes and straight nose are visible. What is important, on the edges there are small holes probably used to attach additional elements or fix it on the head (Ovchinnikova, Kopnina 2000, 133). Such holes are also visible on another leather mask (height $22 \mathrm{~cm}$, width $22 \mathrm{~cm}$ ) (fig. 3e). It is square with oval nar- row eyes, a small triangular nose and a thin mouth (Ovchinnikova, Kopnina 2000, 133). One more mask from this period is just as schematic (height $20.7 \mathrm{~cm}$, width $20.6 \mathrm{~cm}$ ) (fig. 3f), however, in this case the eyes are round and the nose and mouth holes are oval (Ovchinnikova, Kopnina 2000, 134). The latest find of a mask, though in a slightly different form, is also dated to the thirteenth century. It is round and made of leather (height $9 \mathrm{~cm}$, width $9.8 \mathrm{~cm}$ ) (fig. $3 \mathrm{~g}$ ). The shape of the eye holes is irregular and the nose hole is rhomboid. Moreover, mounting holes were placed at both sides (Téra 2017, 306).

The youngest group of artifacts from Veliky Novgorod is dated to the late thirteenth century and the early fourteenth century. The first artifact from the collection is the upper part of a leather mask (height $12.8 \mathrm{~cm}$, width $16.7 \mathrm{~cm}$ ) (fig. 3h) with strongly accentuated eyebrows (Ovchinnikova, Kopnina 2000, 133). The next one has an analogous form yet it is preserved only partially. This leather mask (height $16 \mathrm{~cm}$, width $15.4 \mathrm{~cm}$ ) (fig. 3i) depicts a face with round eye holes, long triangular nose, and narrow oval mouth with visible teeth (Ovchinnikova, Kopnina 2000, 133). The two last masks from the youngest chronological horizon represent very schematic images of faces. They are made of leather with oval eye holes and irregular mouth holes (the size of the first one: height $18.2 \mathrm{~cm}$, width $14.7 \mathrm{~cm}$ - fig. $3 \mathrm{j}$; the second one: height $13.5 \mathrm{~cm}$, width $13 \mathrm{~cm}$ - fig. 3k) (Ovchinnikova, Kopnina 2000, 133-134). The other three specimens from this site are difficult to date. The fragment of the first one has a zoomorphic form and depicts a face with pointed ears and chin (height $28 \mathrm{~cm}$, width $16 \mathrm{~cm}$ ) (fig. 31). The preserved eye holes have a rhomboid shape and there are cuts visible where the mouth should be. Next to the eyes, a hole, probably used to attach the mask, was placed (Ovchinnikova, Kopnina 2000, 132). The last two masks have an anthropomorphic form. The first one is rectangular (height $11 \mathrm{~cm}$, width $14.5 \mathrm{~cm}$ ) (fig. $3 \mathrm{~m}$ ) with round eye holes and small oval cuts for the nose and mouth. On the lower edge a small chin was depicted and at the upper one there is a triangular element and three holes. Another anthropomorphic depiction (height $24.3 \mathrm{~cm}$, width $22 \mathrm{~cm}$ ) (fig. 3n) has a straight upper edge, while the lower one was shaped into a sharp bow. Below the simple round eye holes a rectangular mouth hole was placed, around which a series of small holes were made 
(Ovchinnikova, Kopnina 2000, 134). A direct analogy to the described material can be found among the finds from the stronghold of Lukovec, located in the vicinity of Novgorod. The round mask was made of birch bark (height $20.5 \mathrm{~cm}$, width $24.5 \mathrm{~cm}$ ) (fig. 3o). Two irregular eye holes, a small nose hole and a larger mouth hole were placed in it. Along the entire edge there are further small holes. The object is dated to the tenth through the early eleventh century (Ovchinnikova, Kopnina 2000, 130).

As we can see, the masks from the early medieval Slavic territories may have very different forms. For our discussion the most important are those objects that can be dated to the period between the tenth and twelfth century and associated with the time of pre-Christian traditional religiosity. The younger finds can be a perfect example of the long life of certain religious and cultural traditions. The oldest specimens were made of bark and wood and represent very simple anthropomorphic forms. Leather was used to produce the younger masks, as it was easier to work with and allowed more complex forms. From the twelfth century, attempts at showing facial expressions as well as zoomorphic depictions have been observed. Coming back to the formal description of the artifacts, it is also worth noting that only in the case of some masks are the holes used for fixing them to the face still visible. It seems that using eye holes for this purpose or binding masks firmly with fabrics or thongs could have been a good solution to the problem.

\section{INTERPRETATION}

Helena Cehak-Holubiczowa pointed out the connection between the masks and the New Year rituals (Polish kolęda, caroling), especially the popular tradition called "round with a goat". Such an analysis of the function of the discussed artifacts was supposed to be justified not only by their form, but also the discovery together with one of the masks of wooden zoomorphic figurines, ones interpreted as depictions of goats, (Cehak-Hołubiczowa 1965, 315-317). A similar interpretation, based mostly on ethnographic research (Moszyński 1939, 986-1008), can be found in the latest studies of the finds from Opole - this concerns the proposal by Bogusław Gediga, long-time researcher of early medieval Ostrówek, who places the masks in the context of pre-Christian beliefs (2012, 125-127).
Sławomir Moździoch interprets the finds as relics of pagan rituals that could have survived after the formal conversion of the Piast state (Moździoch 2013, 553): these rituals might have been related to the pagan reaction that took place in the $1030 \mathrm{~s}$ (Moździoch 2013a, 554). Those analyses, mostly referring to Slavic folk culture as comparative material, are to a large extent focused on showing the significant role of masks in the rituals connected with the winter solstice and New Year's. During those rituals participants wore special outfits and masks and their actions were aimed at providing prosperity and fertility, and also referred to the sphere of death and the rebirth of life (Cehak-Hołubiczowa 1965, 316).

The function of masks from the area of Rus' has been interpreted in a similar way. According to Boris Rybakov, they are connected not so much with strictly pagan rituals but those characteristic of the period of so-called dual belief (Russian dvoeverie) (Rybakov 1987, 455-459; on this subject see also: Chamajko 2007, 86-115; Rock 2007, 1-15; Krawiec 2017, 275-276). Bronislava Ovchinnikova divides the collection of the East Slavic masks into zoomorphic, anthropomorphic, and combined depictions. This division is important, because it is supposed to reflect a different purpose of each type. Thus, according to the earlier findings, zoomorphic depictions were supposed to be used during the bear holiday (Russian medvezhiy prazdnik). In more recent works we will find interpretations of the depictions as the images of cats, or even lions (Ovchinnikova 2013, 227). What is interesting, similar masks made of wool - thought to have represented bear muzzles, and dated to the tenth century - were discovered in Hedeby (Back Danielsson 2007, 136-137). Because of their form, they were also interpreted as related to a festival held in honor of those animals. According to the most recent studies, the discussed fragments are elements of hoods rather than masks, without any evident zoomorphic or anthropomorphic connotations (Bregenhøj 2012, 112-113).

Nevertheless, let us return to the artifacts from Veliky Novgorod. The analyses of anthropomorphic and combined masks are more complex. Some scholars saw them as the evidence of the early medieval origins of Russian theater (Awdiejew 1959 ) and the masks were supposed to have been the attributes of itinerant actors and jugglers (Russian skomorokh) known from the medieval culture. Eventually, they were supposed to have served 
as masks used by pagan priests (Russian volkhv) (Ovchinnikova 2013, 228-229). Presently, the most popular interpretation holds that the masks - just like the finds from Opole - were used during Christmas and in the rituals connected with the New Year and carnival (Russian maslenitsa). What is interesting, in Eastern Slavic folk culture masks played a part during the New Year rituals commemorating the dead (Russian igra v pokoynika) (Ovchinnikova, Kopnina 2000, 128). The rituals had a resurrectional character, connected with the winter solstice and masks that were used in them were elements of outfits of the participants dressed up as the dead (Ovchinnikova 2013, 229-230).

\section{DISCUSSION}

Let us try to propose new interpretation possibilities regarding the function and meaning of the Slavic masks and determine the original role they had played before they entered the sphere of folk beliefs and folklore. We will begin the discussion with a definition. The word mask has a different meaning in theater studies, religious studies, psychology, and cultural anthropology. But let us start with etymology. Aleksander Brückner specifies that the Polish word maska comes from the Latin masca, or directly from the French word masque. Such etymology, characteristic of most European languages, shows a direct connection with mascarons, i.e., comedians (Brückner 2000, 324). In Latin there were several terms to describe a mask - which fact will prove important in the analysis of written sources - and the most interesting ones are larva and persona. The first term is the etymological meaning of the Polish word larwa, meaning maska, maszkara, or mara (Brückner 2000, 290). Another one refers to "nightmare, delusion, dream" and originates, in turn, from Proto-Slavic *mara "phantasm, delusion, vision", and probably further from Proto-Indo-European *mer- "gleam, shine, flash", but also "die, perish". Here, in turn, the connection with the Proto-Slavic *mrtvz "dead, lifeless", and Latin mortuus "dead, deceased" (Boryś 2005, 314315 ) is evident. Already on the linguistic level the potential relationship between a mask and death and the world of the dead is visible. As I will try to prove, there are many more elements in pagan Slavic beliefs that confirm such a connection. The Latin word larvae "do magic" (Bańkowski 2000, 5) stems from Indo-European *las-, and its original form lārua, lārva means "mask" and "spirit" at the same time (Pokorny 1959, 654). A mask becomes in such context a metaphor of a larva-chrysalis, and its main task is to enable transformation. The second term is Latin persona, which shows the primal connection between a mask and a person, giving an object dynamic features and agency. Etymology reveals the original meanings ascribed to masks, which reached far beyond the role of covering the face. The Latin persona is a very interesting term when it comes to the psychological role of masks and their direct relationship with the afterlife. Somone who owns the masks of their ancestors is a someone who has a socio-cultural identity that results from belonging to a specific house (Mauss 2001, 190). The living therefore represent their ancestors, and the attributes of a particular persona are simulacra and imagines (Mauss 2001, 191). The mask is an image - a depiction of the dead who had their own personality, which manifests itself through the mask and in the mask. It is then a perfect metaphor of a body, both dead and alive, hiding and revealing itself at the same time.

It is not possible to speak about masks without describing their role in the theater. What is interesting, researchers who are involved in theater studies seek the origins of face covers in pre-Christian religiosity, where they are thought to have been used during ceremonies and religious rituals performed in honor of visitors, guests, and the dead (Hartnoll 1967, 623). The connection between the dead and visitors is visible e.g., in Indo-European ghosti-s, which means "guest, comer, foreigner, enemy", from which stem the German gast as well as the English ghost meaning a "spirit" (Pokorny 1959, 453). Eventually, the mask played a vital role in sacer ludu - theatrical rituals which were supposed to show, first of all, the triumph of life over death. In those rituals there were two actors, one of whom represented life and the other one - death. To be specific, the first one - life that dies; the other one - life that is born (Leeuw 1991, 5). Having a similar character were also the Slavic New Year's rituals, including the already mentioned ritual of making a round with a goat (Kielak 2017, 371-378 - with older literature).

Slavic masks were then endowed with a kind of etiological force. Their role was to change reality. Their metamorphic character referred not only to those who wore them, but also to all participants 
of the ritual who could move to the mythical world thanks to them. This world can reveal itself in a theatrical ritual which is a desacralized form of religious activity. The primal ritual experience of a metamorphosis is then a prototype of acting. The metamorphosis was both internal - psychic, and external - symbolized by a mask. All those elements were in the ancient tradition inseparably connected with the cult of Dionysus, whose mask is an emblem of theater in general and an image of the god at the same time (Kolankiewicz 1999, 46). Gerardus van der Leeuw states in this context that "the god is the mask, the mask is the god" (Leeuw 1991, 6). Dionysus's chthonic competences again show the original connection between theater and veneration of the dead - the first actors "were standing out from the crowd playing the roles of the Dead" (Kolankiewicz 1999, 210).

A mask is supposed to allow its wearer contact with the primal sphere of wild, chaotic nature $($ chthonic $=$ Dionysian element), since "just like nature, or even the state of being wild, was bonded with a mask, a mask has been bonded with a man forever" (Kerényi 2005, 648). In the anthropological understanding the main role of a mask is then creating a common ground for communication with the dead, with gods, and the self (Boholm 2005, 658). Therefore, it is not the form and shape themselves that form the character of a mask and its connections with rituals held in honor of the dead and the afterlife, but the reconstructed context of the ritual use of masks. Our analysis confronts the question: is it possible to show such a role of masks in the context of the religion of the early medieval Slavs? Let us begin the attempt at answering the question with a review of the written sources.

The first interesting passage can be found in Chronica Boemorum by Cosmas of Prague (III, 1). The chronicle cites a decree issued by Prince Břetislav the Younger in 1092, in which the monarch prohibited cultivating pagan funeral rituals during which the participants invoked the souls of the dead, wearing masks and dancing ${ }^{1}$. The con-

1 "Item et supersticiosas instituciones, quasi Villani, adhuc semipagani, in pentecosten tertia sive quarta feria observabant, offerentes libamina super fontes mactabant victimas et demonibus immolabant, item sepultures, que fiebant in silvis et in campis, atque scenas, quas ex gentili ritu faciebant in biviis et in triviis quasi ob animarum pausationem, item et iocos profanes, qous super mortus suos nection between the discussed artifacts and funerary rites, during which the souls of the ancestors are invoked, emerges directly from the text. In the quoted passage masks are the only objects, except people - and the dead - that are involved in rituals consisting in vigorous dances. Unfortunately, the text does not provide any information on the appearance of those items. We may assume that they were attached to the face quite firmly, which enabled dynamic dances. However, we do not know exactly what the relationship between the dancers in masks and the dead was. Were the masks treated as a means of communication with the dead, or were the dressed up participants of the ritual supposed to represent them?

Another fragment does not mention any such mask directly, however, it talks about "a veil" that covers the face, or rather faces of a statue. In the account of Ebon (III, 1), one of the authors of the Life of St. Otto, we can find information on the temple of Triglav (the Three-faced) located in Szczecin. The statue of the god was supposed to have had its faces covered with a golden veil, which made him blind to human sins ${ }^{2}$. Unfortunately, the chronicler does not give any information on the form of the cover. It is worth noting something more about Triglav himself and his mythical competences. The god's character stems directly from the chthonic sphere of the underworld and gained more universal features in the course of the development of the local cult center (Rosik 2010, 264-265). Apart from Szczecin, the place of his veneration was supposedly also located in Brandenburg (see also: Słupecki 1993, 38). According to the findings of scholars who conduct research on the religious beliefs of the Slavs, Triglav is one of the counterparts of Weles, the guardian of the world of the dead, but also wealth, fertility, magic and cattle, whose attributes were gold and a black mount (Gieysztor

inanes cientes manes ac induti faciem larvis bachando exercebant, has abhominationes et alias sacrilegas adinventiones dux bonus (...)" (Cosmas III, 1, 161).

2 "Stetin vero amplissima civitas et maior Iulin tres montes ambitu suo conclusus habebat, quorum medius, qui et alcior, summo paganorum deo Trigelawo dicatus, tricapitum habebat simulacrum, quo aurea cidari oculos et labia contegebat, asserentibus idolorum sacerdotibus ideo summum deum tria habere capita, quoniam tria procura ret regna, id est celi, terre et inferni, et faciem cidari operire pro eo quo peccata hominum, quasi non videns et tacens, dissimularet (...)" (Ebo III, 1, 93). 
2006, 147-153; Dynda 2014, 71-74; Szczepanik $2018,46)$. An offering for the dead, known from the Russian chronicles as trizna, also indicates a direct connection of Weles with the afterlife (Gieysztor 2006, 259). In the Slavic folk tradition the custom survived in most Slavic areas in the form of "a feast for the souls" (Moszyński 1934, 253). Trizna was connected with ritual drinking of alcohol, whose aim was probably to put oneself in a daze, "being a substitute of the mythical ember" (Kowalik 2004, 379). We will find similar elements in the reconstruction of Boris Uspenskij, who assumes that in the Eastern European tradition St. Nicholas took over the competences of pre-Christian Weles. The state of alcohol intoxication was supposed to have been tightly connected with the celebration of the day of this Saint, during which the offering of a three-year-old bull was made - the nikolchshchizna (Uspieński 1985, 76-77). In the offerings, the relation of Triglav and the number three with the afterlife is manifested.

Triglav, reconstructed this way, is an omniscient deity (Pettazzoni 1968, 211-236). Ebo tries to understand the role of the golden mask, using the Christian conceptual apparatus and definition of sin. However, we should assume that this category was unknown in the pre-Christian religion of the Slavs (Szczepanik 2018, 143-144). In this situation, the true role of a mask must have been different. The cover was rather meant to hide the god's faces, as looking directly at them was probably a kind of taboo. The traces of such behavior can be visible in the access to the statue of Svetovid in the temple in Arkona. According to Saxo Grammaticus, the priest who entered the room where the statue was standing held his breath in order not to defile the $\operatorname{god}^{3}$. Triglav's mask could have served a similar role. The crux of the phenomenon is somehow distilled here - covering one face, it shows the other one. Eventually, might the cover on the statue of Triglav have been a kind of divine attribute, similar to the mask of Dionysus? The description shows us

\footnotetext{
3 "Huius sacerdos, praeter communem patriae ritum barbae comaeque prolixitate spectandus, pridie quam rem divinam facere debuisset, sacellum, quod ei soli intrandi fas erat, adhibito scoparum usu diligentissime purgare solebat, observato, ne intra aedem halitum funderet; quo quoties capessendo vel emitiendo opus habebat, toties ad ianuam procurrebat, ne videlicet dei praesentia mortalis spiritus contagio pollueretur (...)" (Saxo XIV, 39, 565).
}

another way masks could have functioned in the religion of the Slavs, different from the one recorded in the chronicle of Cosmas. At the very least, both were connected with the funerary sphere. Masks were used above all in the rituals performed in memory of ancestors - as in the Polish Dziady, during which the dead came as guests in order to warm up and refresh themselves. The rituals were held a couple of times a year and were directly connected with the solar cycle (Szczepanik 2018, 118-120). This connection seems to be clearly confirmed by the mask from Veliky Novgorod decorated with a solar depiction.

When it comes to the form of the known artifacts, the shape of the masks from Opole is worth attention. The items were shaped as extended triangles, which on the one hand may be connected with the simplicity and schematism of the depictions and on the other, its justification might be on a symbolic level. Numerology in the context of traditional cultures is undoubtedly a subject for a separate study (see also: Widomski 1996). However, it is worth mentioning that the number three was supposed to have functioned as a kind of "absolute perfection", being an "ideal image of any dynamic process that allowed the emergence, development and decline, or - in a different scheme - thesis, antithesis and synthesis" (Toporow 1974, 179). Threefoldedness, alongside duality, is also one of the basic characteristics of Slavic cosmology: the reality is divided into the heavenly world, earthly world and underworld (see more: Szczepanik 2018, 4347). The connection is visible in the aforementioned offerings for the dead, such as trizna (see above). Getting back to the triangular shape of the Silesian masks, it is worth paying attention to other artifacts connected with the sphere of the pagan sacrum. In this context the resemblance to the faces decorating the wooden figure of the Svetovid from Wolin is striking (fig. 6). Obviously it is a different category of objects (see also: Szczepanik 2018a, 45-46), however, the way the outlines of particular faces were shaped, with wide and flat forehead and oblong, rounded chin, seem to be highly analogous.

Nonetheless, let us return to the information provided other, though less known written sources (Szczepanik 2012, 111-114). The texts are a bit later than the chronicles discussed above and their message is tightly related to the attempt of Christian clergy at eradicating pagan rituals after the formal introduction of Christianity. The first of the 
documents is a decree of Pope Innocent III dated to January $8^{\text {th }}, 1207$. In the letter we can find the term monstra larvarum (Codex I, doc. 55), meaning "the masks of ghosts, spirits monsters; mascarons", referring to the appearance of the participants of the rituals which were held in cathedrals and churches of the Gniezno Archdiocese in memory of the dead. In the rituals, ones involving the recitation of concrete parts, whole clergy together with the believers actively participated. During those ludi theatrales the participants were wearing masks (Burchardt 1986, 35). Again, we can see the connection between masks and death. It has to be stressed that the rituals were held as late as until the early thirteenth century, and in one of the most important Christian churches in Poland at that time. In the period before the introduction of Christianity, Gniezno's Lech Hill was supposed to have been the site of the cult of Nyja, a goddess called by Jan Długosz the Slavic Pluto $^{4}$. Even though the scholars are rather skeptical about Długosz's pantheon, Nyja seems to raise no doubt when it comes to her pre-Christian character (Brückner 1985, 41-42; Witczak 1994; Strzelczyk 1998, 138; Gieysztor 2006, 197). What is interesting, during the excavations carried out under the church of St. George - the highest point of Lech Hill a stone construction was discovered. Its discoverers are inclined to interpret it as an offering mound (Sawicki 2001, 180), or recently as a kind of a grave of a more or less mythical progenitor (Sawicki 2017, 693). Leaving the issue of the interpretation of this unique archaeological structure for future research, the mythical significance of the Gniezno hill in the process of building a state community directly connected with the memory of ancestors must be emphasized (Szczepanik 2018, 92-95 - with further literature).

We shall now proceed to other written sources and masks that appear in them. In the statute of the archbishop of Gniezno, Janislaus, from February $19^{\text {th }}, 1326$, the term monstris larvarum appears again (Codex II: doc. 1061). The document prohibited the priests and lay people to be present at cemeteries and in churches during services while

4 "Pluthonem cognominabant Nya, quem inferorum deum et animarum, dum corpora linquunt, servatorem et custodem opinabantur; postulabant se ab eo post mortem in meliores inferni sedes deduci et illi delubrum primarium in Gneznensi civitate, ad quod ex omnibus locis fiebat congressus, fabricarunt" (Długosz I, 106). wearing masks (Gloger 1903, 427). The masks used for those rituals are in this situation explicitly interpreted as unclean spirits (Kowalska-Lewicka 1986, 23). In this church prohibition, masks are said to have been used by both clergy and lay people. A new ritual space appears as well - namely, cemeteries, apart from churches. However, the scheme of the ritual acts remains the same.

The presented texts comprise the reactions of church leaders to rituals performed in memory of the dead, during which masks were worn. A minor formal detail of the analyzed artifacts - i.e., the facial expressions visible on some leather masks - can also indicate the connection with funerary rites. As we know from the account of Ibrâhîm ibn Ya qûb, recounted by al-Bakrī, Slavic cremation funerals was supposed to have been accompanied by the joy of the mourners: "They [i.e., the Slavs - P.S.] express their joy loudly and are happy during the cremation process and they claim that their joy and loud rejoicing are caused by the fact that his (i.e., the deceased's) Lord had mercy on him" (Kowalski 1946, 53). The aforementioned joy can be interpreted as a sign of the lack of fear of death and of a positive evaluation of the afterlife (Szczepanik 2018, 113-116 - with older literature). The smile that is visible on some masks can be an echo of the need to hide sadness or other emotions unwanted during a funeral ceremony. From such a perspective the form of particular objects can be seen as connected directly with particular eschatological beliefs.

The selection of the above sources is no coincidence. It shows at least two possible ways masks in the religion of the pagan Slavs functioned. They could have played the role of ritual attributes, or have been a kind of manifestation of the presence of the dead and/or gods connected with the chthonic sphere. To the first group belong the items that are crucial to keep the appropriate course of the ritual. Masks have in this context extremely high dynamis - supernatural etiological force (Belting 2010, 12). We can say that a ritual in honor of the dead is a religious act, not a usual social activity, thanks to those items as well. In such a perspective their aim was to "embody the spirits and the dead who lost their bodies, by lending them official faces" (Belting 2015,44$)$. That was the role the masks could have played in the rituals described by Cosmas and also in the rituals commemorating the dead, prohibited by Pope Innocent III and archbishop Janislaus. 
Masks became essential as means of communication with the world of the dead, being the active "players" in those rituals (see also: Latour 2010, 525-560). They serve basic ritual functions: they invoke the dead, provide contact with them, and provide a kind of protection against negative outcomes of such contacts. It is difficult to say whether they were supposed to protect the participants of a ritual who wore them from being recognized and provide anonymity in the community of the living and dead together, or if their role was to serve as protection against other magical procedures. Undoubtedly, they lent human actions a new dimension. A man wearing a mask stopped being himself and became the character represented by the mask (Leeuw 1991, 6).

Masks could have been images as well - depictions of the dead. According to Leszek Kolankiewicz, a scientists who studies the pagan origins of theater, initially all ritual masks represent the souls of the dead and "dances in masks are always the dances of spirits" (Kolankiewicz 1999, 46). From such a perspective the masked participants of rites not only are supposed to enable communication with the dead, but they become one of them. A mask, as a ritual attribute, is a tool that allows religious acts to proceed in an appropriate way. It enables the participants of a ritual to communicate with the dead, allowing their presence and unification with them (Szczepanik 2012, 113-114). Unfortunately, we do not know if masks had any special role or were a cult object beyond the celebrations. It seems that they could have been deprived of their symbolic meaning only after a rite came to an end. Such a course of events seems to be indicated by the contexts of the discovery of particular artifacts in the layers of litter. Making masks using organic materials that are easy to work with (AldhouseGreen 2005, 96), but also prone to manipulation and damage, seems to suggest that the items were made for a specific ritual purpose and after fulfilling it they lost their high symbolic status and were destroyed and thrown away.

Masks may also have played an important role in other spheres of the Slavic religiosity - for instance, as the image of a deity available for the eyes of the followers. In this perspective a mask is supposed to "protect the god and hide it at the same time - recall it yet not reveal it" (Leeuw 1997, 391). Maybe this is how the function of the golden veil protecting the face of Triglav should be in- terpreted? From this point of view, the veil, being a kind of a religious fetish, would be an object that determines ritual behavior (Szczepanik 2012, 115116). The activity includes the behavior "for it and through it", not only "with the use of it", as it is in the case of attributes - props. Thanks to that, a fetish can be perceived as the image of a god (Leeuw 1997, 33). The mask of Triglav so understood becomes a numinous embodiment of sacred content materialized in a specified object (Otto 1999, 10). The golden artifact represented the deity, providing communication between the earthly and divine spheres. We have already rejected the interpretation in the spirit of interpretatio christiana, assuming that the category of sin functioned in the religion of the pagan Slavs. Now we can see that the cover may have allowed communication rather than mitigated it (Belting 2015, 12-14). It was the mask that became the element focusing all the sacred power - probably also due to the material it was made of. It could have belonged to the category of "sacred objects", which Maurice Godelier $(2010,149)$ calls "objects that replace people and gods".

This analysis shows the possibility of looking at masks as items that played an extremely important role in the pre-Christian religion of the Slavs. Thus, the interpretation path adopted here presents one of the possibilities for analysis of this really interesting group of artifacts, showing their original connection with the world of the dead. This statement is consistent with the early medieval Slavic material, the studies of anthropology of images carried out by Hans Belting $(2015,46)$, according to whom "the history of masks also reflect the origins of the veneration of the dead and the cult of gods". Even the small number of sources that we have lets us examine these unique artifacts from at least two different perspectives. They can serve as ritual attributes. Masks made of organic materials discovered during archaeological excavations and associated with rituals commemorating the dead can be an example. On the other hand, they can be regarded as images of the dead or even the gods that take care of them, which can be proved by some of the written sources. With the progress of Christianization, masks, just like other elements of the pagan past, underwent a metamorphosis from items connected with the sphere of religious activities into an element of folk culture such as the custom of caroling still known today, in which the echoes of eschatological rites are still visible. 


\section{BIBLIOGRAFIA}

\section{Źródla:}

Kosmas Cosmae Pragensis Chronica Boemorum, Monumenta Germaniae Historica. Scriptores Rerum Germanicum. Nova Series. Tomus II, B. Bretholz (hrsg.), Berlin 1923.

Długosz Ioannis Dlugossii, Annales seu Cronicae incliti Regni Poloniae, Liber Primus. Liber Secundus, ed. I. Dąbrowski, Warszawa 1964.

Ebo Ebonis Vita s. Ottonis Episcopi Babenbergensis, Monumenta Poloniae Historica. Series Nova. Tomus VII, Fasc. 2, J. Wikarjak (red.), Warszawa 1969.

Kodeks Kodeks dyplomatyczny Wielkopolski obejmujący dokumenta tak już drukowane, jak dotąd nie ogłaszane, siegajace do roku 1400, Poznań 1878.

Saxo Saxonis Grammatici Gesta Danorum, A. Holder (red.), Strassburg 1886.

Ibrāhīm Relacja Ibrāhīma ibn Ja'qūba z podróży do krajów słowiańskich w przekazie al-Bakrīego, Monumenta Poloniae Historica. Seria II - t. I, T. Kowalski (red.), Kraków 1946.

\section{Literatura:}

Aldhouse-Green M. (2005). An Archaeology of Images. Iconology and cosmology in Iron Age and Roman Europe. London: Routledge.

Awdiejew A.D. (1959). Proischożdienije teatra. Elementy tieatra $v$ pervobytnoobsinnom stroe. LeningradMoskva: Iskusstvo.

Back Danielsson I.-M. (2007). Masking Moments. The Transitions of Bodies and Beings in Late Iron Age Scandinavia. Stockholm: Stockholm University.

Bańkowski A. (2000). Etymologiczny słownik języka polskiego. Warszawa: Wydawnictwo Naukowe PWN.

Belting H. (2010). Obraz i kult. Historia obrazu przed epoka sztuki. Gdańsk: Wydawnictwo Słowo/Obraz Terytoria.

Belting H. (2015). Faces. Historia twarzy, przekł. T. Zatorski. Gdańsk: Wydawnictwo Słowo/Obraz Terytoria.

Boholm Å. (2005). Weneckie widowiska karnawałowe w maskach. W: L. Kolankiewicz (red.), Antropologia widowisk: zagadnienia i wybór tekstów (658-667). Warszawa: Wydawnictwo Uniwersytetu Warszawskiego.

Boryś W. (2005). Słownik etymologiczny języka polskiego. Kraków: Wydawnictwo Literackie.
Brisbane M. (red.) (1992). The archaeology of Novgorod, Russia: Recent results from the town and its hinterland. Lincoln: Society for Medieval Archaeology.

Brisbane M., Hather J.G. (2007). Wood Use in Medieval Novgorod. Oxford: Oxbow.

Bregenhøj C. (2012). The Masks of Hedeby in Historic and Ethnological Perspective. W: H. Meller, R. Maraszek (red.), Masken der Vorzeit in Europa (II). Internationale Tagung vom 19. Bis 21. November 2010 in Halle (Saale) (111-120). Halle (Salle): Landesamt für Denkmalpflege und Archäologie Sachsen-Anhalt, Landesmuseum für Vorgeschichte.

Brückner A. (1985). Mitologia słowiańska i polska, wstęp i oprac. S. Urbańczyk. Warszawa: Państwowe Wydawnictwo Naukowe.

Brückner A. (2000). Słownik etymologiczny języka polskiego, wyd. IX. Warszawa: PW Wiedza Powszechna.

Bukowska-Gedigowa J., Gediga B. (1986) Wczesnośredniowieczny gród na Ostrówku w Opolu. WrocławWarszawa-Kraków-Gdańsk-Łódź: Zakład Narodowy im. Ossolińskich.

Burchardt J. (1986). Dlaczego pogańscy Polanie w XI w. nie zniszczyli katedry gnieźnieńskiej? Literatura $\mathrm{Lu}$ dowa, 1, 31-42.

Cehak-Hołubiczowa H. (1965). Drewniane maski z grodumiasta na Ostrówku w Opolu. Archeologia Polski, $X / 1,305-317$.

Chamajko N. (2007). Driewnierusskoje „dwojewierija”: proischożdienije, sodierżanije i adiekwatnost' tiermina. Ruthenica, 6, 86-115.

Dynda J. (2014). The Three-Headed One at the Crossroad: A Comparative Study of the Slavic God Triglav. Studia Mythologica Slavica, 17, 57-82.

Gediga B. (2012) Frühmittelalterliche Holzmasken aus Opole-Ostrówek. W: H. Meller, R. Maraszek (red.), Masken der Vorzeit in Europa (II). Internationale Tagung vom 19. Bis 21. November 2010 in Halle (Saale), (121-128), Halle (Salle): Landesamt für Denkmalpflege und Archäologie Sachsen-Anhalt, Landesmuseum für Vorgeschichte.

Gieysztor A. (2006). Mitologia Słowian, wyd. III, Warszawa: Wydawnictwo Uniwersytetu Warszawskiego.

Gloger Z. (1903). Encyklopedja staropolska. Ilustrowana, t. 4. Warszawa: Drukarnia P. Laskauera i S-ki.

Godelier M. (2010). Zagadka daru. Kraków: Wydawnictwo Uniwersytetu Jagiellońskiego.

Gutjahr M. (2012). Masken im Mittelalter - ein Überblick. W: H. Meller, R. Maraszek (red.), Masken der Vorzeit 
in Europa (II). Internationale Tagung vom 19. Bis 21. November 2010 in Halle (Saale) (143-161). Halle (Salle): Landesamt für Denkmalpflege und Archäologie Sachsen-Anhalt, Landesmuseum für Vorgeschichte.

Hartnoll P. (1967). The Oxford companion to the theatre. London: Oxford University Press.

Kerényi K. (2005). Człowiek i maska. W: L. Kolankiewicz (red.), Antropologia widowisk: zagadnienia $i$ wybór tekstów (647-657). Warszawa: Wydawnictwo Uniwersytetu Warszawskiego.

Kielak O. (2017). Gdzie koza chodzi, tam żyto rodzi. Płodnościowa funkcja kolędowania z maszkarą kozy. Polska sztuka ludowa. Konteksty, 71/1-2, 371-378.

Kolankiewicz L. (1999). Dziady. Teatr święta zmartych. Gdańsk: Wydawnictwo Słowo/Obraz Terytoria.

Kolchin B.A. (1985). Drevnij Novgorod: prikladnoe iskusstvo i arheologiâ. Raskopy, gramoty, pismennost', muzykalnye instrumenty, maski, šahmaty, vislye pečati, cvetnoj metall, kost', derevo, steklo, ântar', kamen', glina, koža, železo. Moskva: Iskusstvo.

Kowalik A. (2004). Kosmologia dawnych Stowian. Prolegomena do teologii politycznej dawnych Stowian. Kraków: Zakład Wydawniczy „Nomos”.

Kowalska-Lewicka A. (1986). Ludowe wyobrażenia śmierci. Polska sztuka ludowa, 40/1-2, 23-30.

Krawiec A. (2017). Konsekwencje chrystianizacji dla społeczności i społeczeństw „Młodszej Europy”. W: J. Dobosz, J. Strzelczyk, M. Malta (red.), Chrystianizacja „Młodszej Europy”(273-292). Poznań: Wydawnictwo Naukowe Uniwersytetu im. Adama Mickiewicza w Poznaniu.

Latour B. (2010). Przedmioty także posiadają sprawczość. W: E. Domańska (red.), Teoria wiedzy o przeszłości na tle wspótczesnej humanistyki. Antologia (525-560). Poznań: Wydawnictwo Poznańskie.

Leeuw G. (1991). Święta gra. Polska Sztuka Ludowa. Konteksty, 45/3-4, 4-10.

Łowmiański H. (1979). Religia Stowian i jej upadek (w. VIXII). Warszawa: Państwowe Wydawnictwo Naukowe.

Mauss M. (2001). Pojęcie osoby, pojęcie ,ja”. W: A. Mencwel (red.), Antropologia kultury. Zagadnienia $i$ wybór tekstów (187-190). Warszawa: Wydawnictwo Uniwersytetu Warszawskiego.

Moszyński K. (1934). Kultura ludowa Stowian, Kultura duchowa, Część II. Zeszyt 1 cz. II. Kraków: Polska Akademia Umiejętności.

Moszyński K. (1939). Kultura ludowa Stowian. Kultura duchowa, Część II. Zeszyt 2. Kraków: Polska Akademia Umiejętności.

Moździoch S. (2013). Holzmaske aus Kiefer. W: C. Stiegemann, M. Kroker, W. Wolter (red.), Credo. Christiani- sierung Europas im Mittelalter, Bd. II, Katalog (553554). Petersberg: Michael Imhof Verlag.

Moździoch S. (2013a). Holzmaske aus Kiefer. W: C. Stiegemann, M. Kroker, W. Wolter (red.), Credo. Christianisierung Europas im Mittelalter, Bd. II, Katalog (554). Petersberg: Michael Imhof Verlag.

Otto R. (1999). Świętość. Elementy irracjonalne w pojęciu bóstwa $i$ ich stosunek do elementów racjonalnych. Warszawa: Wydawnictwo „KR”.

Ovchinnikova B.B. (2013). Litsevyye maski v srednevekovoy kul'ture Rusi (po materialam Novgorodskoy arkheologicheskoy ekspeditsii). W: V.A. Borzunov (red.), Arkheologiya Severa Rossii. Ot epokhi zheleza do Rossiyskoy imperii. Materialy Vserossiyskoy nauchnoy arkheologicheskoy konferentsii (227-232). Jekaterynburg - Surgut: Institute of Archaeology of the Russian Academy of Sciences.

Ovchinnikova B.B., Kopnina E.W. (2000). Maski i ikh rol v srednevekovoy kulture Novgoroda. W: A.T. Shashkov (red.), Problemy istorii Rossii. Vyp. 3. Novgorodskaya Rus'. Istoricheskoye prostranstvo i kul'turnoye naslediye (118-134). Jekaterynburg: Uralski Universitet.

Pettazzoni R. (1968). Wszechwiedza bogów. Warszawa: Książka i Wiedza.

Pokorny J. (1959). Indogermanisches etymologisches Wörterbuch. Bern-München: Francke Verlag.

Rosik S. (2010). Conversio gentis Pomeranorum. Studium świadectwa o wydarzeniu (XII wiek). Wrocław: Wydawnictwo Chronicon.

Rybakov B.A. (1987). Jazyczestwo Drewnej Rusi. Moskwa: „Nauka”.

Sawicki T. (2001). Badania przy kościele św. Jerzego $w$ Gnieźnie. W: Z. Kurnatowska (red.), Gniezno w świetle ostatnich badań archeologicznych. Nowe fakty, nowe interpretacje (163-186). Poznań: Wydawnictwo Poznańskiego Towarzystwa Przyjaciół Nauk.

Sawicki T. (2017). Przedchrześcijańska konstrukcja kamienna na Górze Lecha w Gnieźnie. W: A. Różański (red.), Gemma Gemmarum. Studia dedykowane Profesor Hannie Kóčce-Krenz (679-705). Poznań: Wydawnictwo Poznańskiego Towarzystwa Przyjaciół Nauk.

Sikorski D.A. (2018). Religie dawnych Stowian. Przewodnik dla zdezorientowanych. Poznań: Wydawnictwo Poznańskie.

Słupecki L.P. (1994). Slavonic Pagan Sanctuaries. Warsaw: Institute of Archaeology and Ethnology. Polish Academy of Science.

Strzelczyk J. (1998). Mity, podania $i$ wierzenia dawnych Słowian. Poznań: Rebis. 
Szczepanik P. (2012). Maski w kulturze pogańskich Słowian Zachodnich. Atrybut rytualno-obrzędowy, czy fetysz religijny? W: M. Franz, Z. Pilarczyk (red.), Barbarzyńcy u bram. Mare Integrans. Studia nad dziejami wybrzeży Morza Battyckiego. Wolin 5-7 sierpnia 2011 (104-121). Toruń: Wydawnictwo Adam Marszałek.

Szczepanik P. (2018). Słowiańskie zaświaty. Wierzenia, wizje i mity. Szczecin: Wydawnictwo „Triglav”.

Szczepanik P. (2018a). Wczesnośredniowieczne figurki miniaturowe z terenów Słowiańszczyzny Północno-Zachodniej. Próba interpretacji. W: S. Rosik, S. Jędrzejewska, K. Kollinger (red.), Hierofanie, wierzenia, obrzędy... Kultura symboliczna w'średniowieczu między pogaństwem a chrześcijaństwem. Materiaty V Kongresu Mediewistów Polskich, t. II (43-67). Rzeszów: Wydawnictwo Uniwersytetu Rzeszowskiego.
Téra M. (2017) Perun bůh hromovládce. Sonda do slovanského archaického náboženství. Červený Kostelec: Pavel Mervart.

Toporow W.N. (1974). O modelach liczbowych w kulturach archaicznych. Teksty. Teoria literatury, krytyka, interpretacja, 1(13), 167-188.

Uspieński B.A. (1985). Kult św. Mikołaja na Rusi. Lublin: Redakcja Wydawnictw Katolickiego Uniwersytetu Lubelskiego.

Widomski J. (1996). Ontologia liczby. Wybrane zagadnienia z ontologii liczby w starożytności i średniowieczu. Kraków: Wydawnictwo Uniwersytetu Jagiellońskiego.

Witczak K.T. (1994). Ze studiów nad religia Prasłowian. Część 2: Prapolska Nyja a grecka Enyo. Slavia Occidentalis, 51, 123-132.

Otrzymano (Received): 20.12.2019; Zrecenzowano (Revised): 19.03.2020; Zaakceptowano (Accepted): 20.04.2020

Adres Autora:

Dr Paweł Szczepanik

Instytut Archeologii

Uniwersytet Mikołaja Kopernika w Toruniu

Szosa Bydgoska 44/48

87-100 Toruń

e-mail: pawelszczepanik@umk.pl

iD https://orcid.org/0000-0002-0259-0169 